BARRIERS VS. BRIDGES: UNDOCUMENTED IMMIGRANTS' ACCESS TO POST-SECONDARY EDUCATION IN THE UNITED STATES AND CANADA

\author{
by \\ Marietta Armanyous \\ BA (Hons.), University of Toronto, 2016 \\ A Major Research Paper \\ presented to Ryerson University \\ in partial fulfillment of the requirements for the degree of \\ Master of Arts \\ in the Program of \\ Immigration and Settlement Studies
}

Toronto, Ontario, Canada, 2019

(C) Marietta Armanyous, 2019 


\section{AUTHOR'S DECLARATION FOR ELECTRONIC SUBMISSION OF A MAJOR RESEARCH PAPER (MRP)}

I hereby declare that I am the sole author of this MRP. This is a true copy of the MRP, including any required final revisions.

I authorize Ryerson University to lend this MRP to other institutions or individuals for the purpose of scholarly research.

I further authorize Ryerson University to reproduce this MRP by photocopying or by other means, in total or in part, at the request of other institutions or individuals for the purpose of scholarly research.

I understand that my MRP may be made electronically available to the public.

Marietta Armanyous 


\title{
BARRIERS VS. BRIDGES: UNDOCUMENTED IMMIGRANTS' ACCESS TO POST-SECONDARY EDUCATION IN THE UNITED STATES AND CANADA
}

\author{
Marietta Armanyous \\ Master of Arts 2019 \\ Immigration and Settlement Studies \\ Ryerson University
}

\begin{abstract}
There is limited research available on the issue concerning undocumented immigrants' access to post-secondary education in the Canadian context. This paper addresses this matter by highlighting the pro-access efforts currently being made in Canada and outlining various actions taken in the United States (US), which Canada can also implement. Guided by the human right to education as its theoretical framework, this paper examines the existing barriers to accessing post-secondary education that this particular marginalized group faces in Canada and the US. It assesses the policies that US state governments, US universities, and Canadian universities implemented (or plan to implement) to remove these barriers, thereby allowing undocumented immigrants to obtain formal post-secondary education.
\end{abstract}

Key Words: undocumented immigrants; post-secondary education; human right to education; Canada; United States 


\section{ACKNOWLEDGEMENTS}

First and foremost, I would like to express my immense gratitude for my family's unwavering love, patience, and support. My parents have always put their children's well-being first, willing to do whatever is necessary to provide my brother and me with the best lives possible - regardless of what cards we were dealt. I am thankful for their endless sacrifices, both big and small, that have brought me to where I am today. This MRP is dedicated to them, as well as my brother, who moonlights as my editor.

I would also like to extend my thanks to Dr. Graham Hudson, my MRP supervisor, for his enthusiasm regarding this paper's topic and overall guidance throughout the writing process. Dr. Hudson, along with my second reader Dr. Idil Atak, provided me with ample positive feedback and useful advice that I will take with me going forward. Thank you. 


\section{Table of Contents}

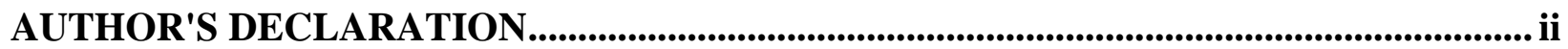

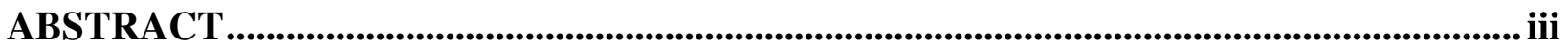

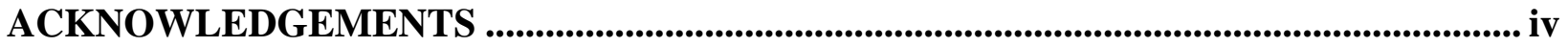

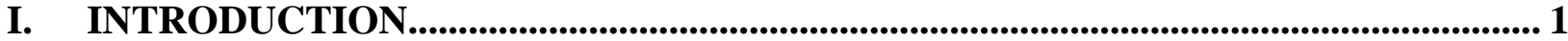

RESEARCH STATEMENT AND RESEARCH QUESTIONS ......................................................... 1

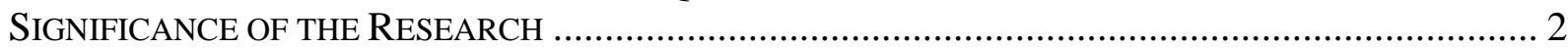

II. POSITIONALITY STATEMENT ........................................................................... 3

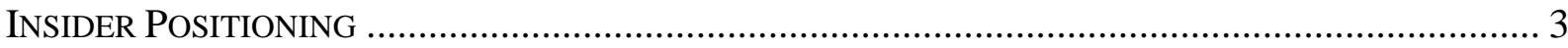

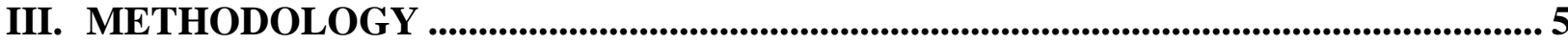

OPERATIONALIZING THE TERM “UNDOCUMENTED IMMIGRANT”,............................................. 5

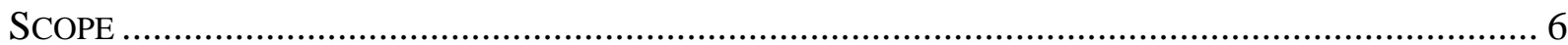

APPROACH: EXTENSIVE LITERATURE REVIEW ................................................................ 7

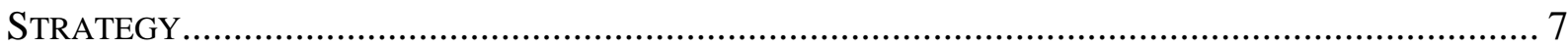

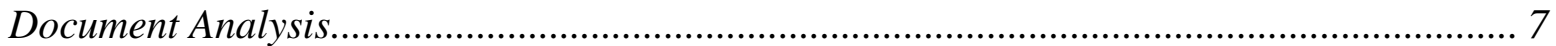

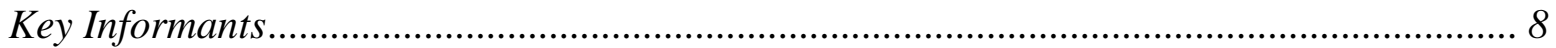

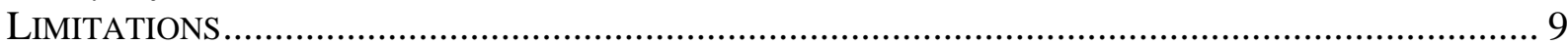

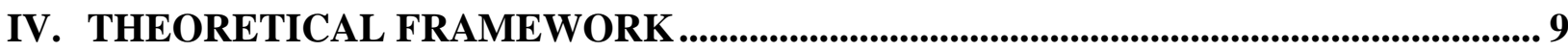

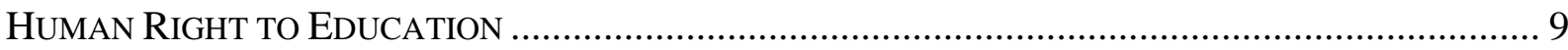

V. OVERVIEW OF THE TOPIC: UNDOCUMENTED IMMIGRANTS ....................... 17

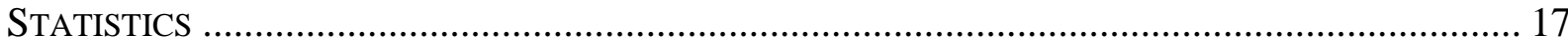

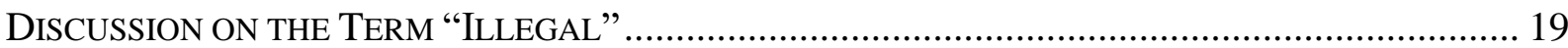

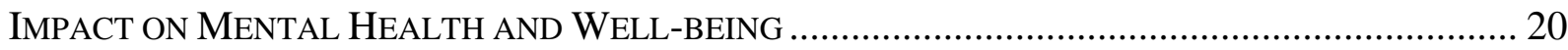

VI. ACCESS GRANTED TO PRIMARY AND SECONDARY SCHOOLS ..................... 21

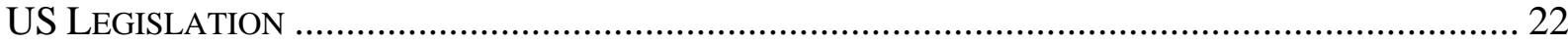

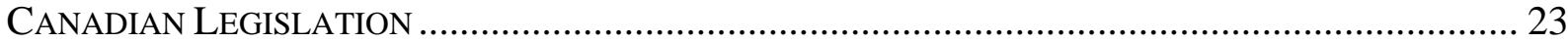

VII. THE DEBATE OVER PROVIDING ACCESS TO POST-SECONDARY

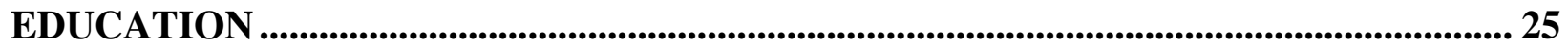

VIII. BARRIERS TO ACCESSING POST-SECONDARY EDUCATION ........................ 27

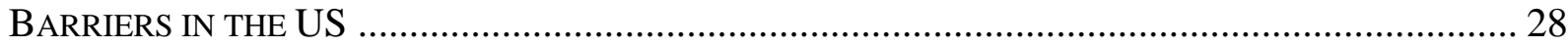

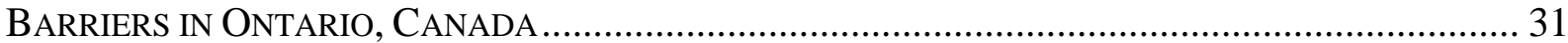

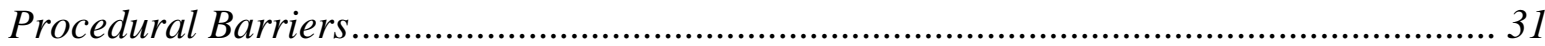

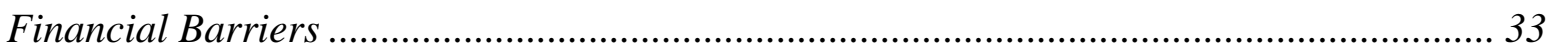

IX. EFFORTS MADE BY US STATE GOVERNMENTS .......................................... 35

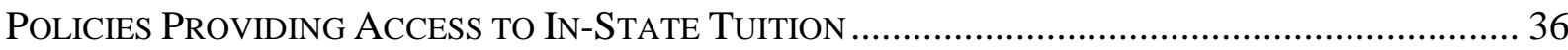

Policies Providing ACCESS to State FinANCIAL Aid .................................................... 38 
X. EFFORTS MADE BY US UNIVERSITIES ...................................................................... 40

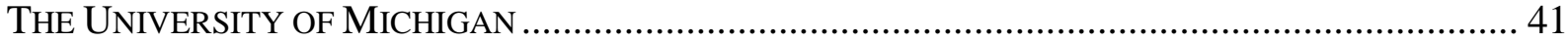

THE UNIVERSITY OF HAWAII AND THE UNIVERSITY OF MAINE................................................ 43

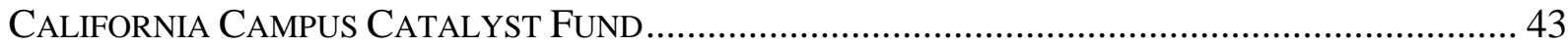

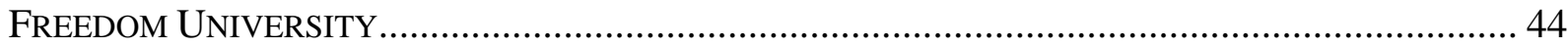

XI. THE CANADIAN INITIATIVE .................................................................................... 46

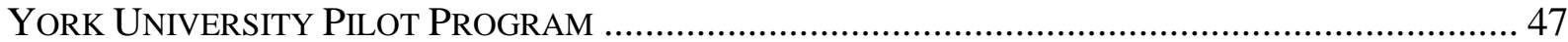

UNIVERSITY OF TORONTO PROPOSAL ……………............................................................ 49

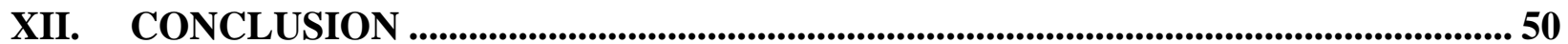

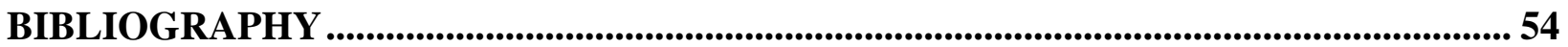




\section{Introduction}

A contentious matter that has been debated in numerous societies throughout history is that of immigration. Leading up to present day, the issue regarding how to address this portion of the population has only become more prominent, resulting in polarized factions with opposing opinions. In particular, undocumented immigrants are one specific group that is often discussed.

While undocumented migration has existed for centuries, states that currently experience this movement struggle to agree on a way to respond to it. Governmental institutions must decide whether or not immigrants who are already living in the country without formal legal status should be given access to public services, such as health and education. The latter is of particular interest in this paper, as there is international legislation that declares education to be a basic human right. Meanwhile, there are respective domestic policies both for and against providing this marginalized population with access to education. Thus, it is important to review current policies and see whether or not undocumented immigrants have access to this social human right.

\section{Research Statement and Research Questions}

This Major Research Paper (MRP) examines the existing barriers to accessing postsecondary education that undocumented immigrants face in Canada and the United States (US). It assesses the policies that various US state governments, US universities, and Canadian universities implemented (or plan to implement) to remove these barriers, thereby allowing undocumented immigrants to obtain formal post-secondary education.

Essentially, this paper will assess an undocumented immigrant's ability (or inability) to access post-secondary education in Canada and the US. Primarily, it will discuss policies that certain US state governments and universities passed to provide undocumented immigrants with 
this opportunity, in contrast to other states' policies that inhibit one's ability to access higher education. It will also use these experiences to interpret similar Canadian policies, practices, and advocacy.

The first portion of the MRP provides an overview of the discourse related to immigrants in this precarious situation, including: the term "illegal" and its political weight, the impact that being undocumented has on one's mental health, the debate surrounding access to post-secondary education, along with the access to primary education that was granted. The second portion of the MRP looks at the barriers to accessing post-secondary education in the US and Canada, followed by the efforts (not) made in the respective countries to reduce these impediments.

The primary questions that this research paper will address are the following:

- For undocumented immigrants in the US and Canada, are there legal, procedural, and/or financial barriers to accessing post-secondary education? If so, what are they?

- What policies are state/provincial governments implementing to remove these barriers?

- What policies are US/Canadian universities implementing to remove these barriers?

\section{Significance of the Research}

Undocumented immigrants are a topic that is often discussed in today's media, although it mainly focuses on the situation in the US. However, undocumented immigrants also live in Canada and face similar challenges to those residing in the US. Therefore, it is important to highlight the barriers-particularly one's access to higher education - in the Canadian context. By addressing the key obstacles and providing examples of policies already implemented in the US in an effort to eliminate these barriers, Canadians can seek appropriate policy changes to resolve this issue. With far less information on the topic of post-secondary education access in the Canadian context, 
along with a lack of discussion on how to address it, it is an important matter to bring to the forefront of both Canadian immigration and education policy discussions.

While this marginalized group faces several hindrances, the individuals directly affected are not able to fully address these challenges, primarily because of their precarious legal situations. It is important to advocate with and, when necessary, on behalf of undocumented migrants; this is one of the aims of this paper. My research will help shed more light on this concern and amplify the need for governments/institutions to find pragmatic ways to resolve this issue.

\section{Positionality Statement}

\section{Insider Positioning}

It is important for the reader to be aware of the author's position on the issue being discussed; it allows the reader to better understand the point of view from which the paper is being written and certain biases to which they may be disposed. According to Merriam et al. (2001), "What an insider 'sees' and 'understands' will be different from, but as valid as what an outsider understands" (p. 415). Nevertheless, one should disclose their relation to the issue, along with whether they consider themselves to be an insider or an outsider. Regarding my positionality, I fall under the insider category because I am very familiar with the particular situations discussed in this paper. I experienced both the difficulties surrounding access to public services first-hand when I lived in the US as an undocumented immigrant, as well as the accessibility available to me in Canada where I live as a resident with legal status.

I arrived in the US as a minor alongside my parents and brother, seeking asylum. After submitting our application, all there was left to do was wait for a decision. Due to various complications, my family waited for 12 years, during which time I was raised in the US and 
completed all of my primary education and some secondary education. Throughout my schooling, I always put substantial effort into my work, with the strong encouragement and support from my parents. Raised to be a hardworking, high achiever, my goal was to be a student who had both academic and extracurricular achievements. Like many of today's "DREAMers", I believed that my efforts would provide me with a chance to pursue my higher education at a well-recognized US university—not realizing the precarious situation my family was in, which would prevent me from achieving this objective.

With only two years left until I graduated from high school, and even less time before I had to start applying to post-secondary institutions, my family felt that we would benefit more by leaving the lives we had established in the US than by continuing to live there without any legal status. And so, we did. Canada seemed to be a viable option, due to its geographical and cultural ties to the US, as well as its skill-based immigration policy referred to as the "points system" (Walsh, 2011). While my family's immigration application was being processed, I obtained a student visa and finished my secondary school studies in Canada as an international student. This was largely made possible thanks to financial support from extended family and friends to help pay for my international student tuition fees.

After receiving the great news that our application was accepted, my family and I became Permanent Residents. Then, I was able to pursue post-secondary education in Canada as a domestic student. While this difficult journey concluded in my favour, it was primarily because my parents made the pivotal decision to leave the US after 12 years to pursue a different country's immigration pathway, from which we were accepted. Unfortunately, I hear stories of distress and insecurity from individuals who are in the same precarious situation that I was once in, without a feasible solution. This places me in a position where I feel sympathetic for persons without legal status in 
a country that they spent a majority of their lives in and viewed as their home, particularly because I once faced these unstable circumstances myself.

My insider position may pose a challenge as I could have the predisposition to empathize with undocumented immigrants and feel strongly that policy changes should be made to accommodate this group. Nevertheless, I will address both the arguments for and against access in the paper, to provide the reader with both sides of the debate. Simultaneously, my positionality is also a strength, as I was both a US and Canadian immigrant; this allows me to compare the two distinctly different experiences and understand how powerful it feels to obtain formal legal status, thereby becoming "legitimate" within society.

\section{Methodology}

\section{Operationalizing the Term "Undocumented Immigrant"}

It is important to define exactly what I mean when I use the term "undocumented immigrant" throughout this MRP. These individuals are often referred to as "illegal" immigrants in the public discourse, which will be further discussed later in this paper. However, "illegal immigrant" is considered to be a racially charged term with a purposely negative connotation and hence should not be used (DACA and Undocumented Students, 2019). There are several situations in which an individual would be considered "undocumented", meaning they do not hold any legal status in the country where they are residing. The ways in which one could become undocumented include:

- Entering the country legally (e.g. travel visa, student visa, temporary worker) and overstaying past the visa's expiration date. 
- Entering the country legally seeking asylum; staying in the country after the refugee claim is denied.

- Entering the country legally through an official port of entry, but using fraudulent documents.

- Entering the country illegally, as in not through designated official border crossings. While this method is less common than the ones above, it is often the one that is mainly focused on by the North American media. (Wilson, 2009, p. 7; Simich, Wu, \& Nerad 2007, p. 369). Also, these individuals may have entered of their own will as adults, or may have been minors at the time and entered with their parents/guardians. The term is synonymous with being "irregular" or lacking legal status in the country where one currently lives. Hence, individuals who are in any of these situations are who I am referring to when I use the term "undocumented immigrant."

$\underline{\text { Scope }}$

Most of the research completed in this MRP focuses on the US, mainly because there is significantly more literature available on efforts made in the US than in Canada. Nevertheless, any Canadian projects and/or policies that positively (or negatively) affect undocumented immigrants' access to post-secondary education will also be discussed. In particular, the province of Ontario will be assessed when looking at accessibility, or lack thereof, in Canada.

The research looks at the US and Canada because these countries are not only adjacent to one another, but also have comparable socio-economic conditions and political systems. Thus, these similarities imply that publications that discuss US-based policies would likely be applicable to Canada as well. 


\section{Approach: Extensive Literature Review}

Since this MRP is exploratory, an extensive literature review and document analysis (when applicable) is the optimal method. An analysis of published articles that discuss policies-which institutions and/or government bodies implemented to offer or impede access to post-secondary education for undocumented immigrants - will be conducted to review the efforts made in various jurisdictions (states; public/private school boards; etc.). In addition to the publications that provide sufficient information on the respective policies being discussed, the policy documents will be directly accessed to further analyze the Act/Bill in question. In an effort to make this paper as reliable as possible, I use this method of obtaining information directly from legal documents along with cross-checking factual statements made in journal articles to ensure that they are accurate. This methodology allows me to see the policies currently in place that either encourage or inhibit undocumented immigrants from accessing post-secondary education.

\section{$\underline{\text { Strategy }}$}

\section{$\underline{\text { Document Analysis }}$}

I plan to find the appropriate literature by searching: scholarly journal databases; Ryerson library catalogue; dissertations; subject-specific professional websites; and official websites of institutions that are involved. For the document analysis, I will search for the policies on the official state and university websites that provide full-length online versions of the text.

The key terms that will be used to search for relevant articles include:

- undocumented/unauthorized/irregular/illegal/illegalized

- immigrants/migrants

- post-secondary/college/university 
- access/access without fear/opportunity/barrier

- sanctuary/solidarity

- youth/minors

As for the criteria that will be used to choose which literature will be included, the articles must be relevant to the topic and address the geographical region being discussed in this paper. As previously mentioned, while the issue regarding accessibility to post-secondary education may exist in numerous countries, this MRP focuses on how this issue is addressed in North Americaparticularly the US and Canada.

\section{$\underline{\text { Key Informants }}$}

In an effort to obtain more information on Canadian universities' current and/or prospective programs that would provide undocumented immigrants with access to post-secondary education, this MRP includes information learned through informal correspondence with key informants on these particular initiatives. In the province of Ontario, York University (YorkU) has already implemented a pilot program that offers access to students with precarious immigration status, and the University of Toronto (UofT) is in the process of establishing a similar one. Unfortunately, published articles and data about the progressive efforts being made in these public universities are limited. Therefore, YorkU and UofT faculty members who are involved in these initiatives were contacted to expand on what these programs entail. Within their professional capacities, these faculty members and I discussed the topic of providing undocumented immigrants with access to Canadian post-secondary education at YorkU and UofT, respectively. After inquiring with the Ryerson Ethics Board (REB) about obtaining research data through informal 
conversations with key informants, the REB confirmed that this project is exempt from REB review.

\section{Limitations}

Even though the issue is slowly gaining traction in Canada, there is still limited literature on Canada's efforts to provide access to post-secondary education for undocumented immigrants. This may be a constraint, but it presents a gap in the literature that this MRP could help fill. Although there is minimal Canada-specific information, a significant amount of literature regarding US policies is available. While it is not ideal, the US and Canada's geographical proximity to one another, along with their cultural and socio-economic similarities, allow me to take advantage of this literature. US policies and initiatives offer useful insight as to how the Canadian government and its institutions could address this issue.

\section{Theoretical Framework}

\section{Human Right to Education}

Due to the increasing securitization of immigration, a trend that has risen significantly in the post-9/11 era, immigrants experience restrictions not only on their basic political and civil rights, but on social human rights - under which education falls (Crépeau, Nakache, \& Atak, 2007, p. 311). This is particularly applicable to immigrants who are in even more precarious situations by having no legal status in the country where they reside.

This research paper is guided by the human right to education as its theoretical framework. While this may be a contentious standpoint, education is arguably a basic human right. According to the United Nations Human Rights Office of the High Commissioner (OHCHR), the rationale 
behind this notion is that "the right to education unlocks other rights when guaranteed, while its denial leads to compounded denials of other human rights and perpetuation of poverty" (UN Commission on Human Rights, 2004, p. 7). Essentially, one's access to education is necessary not only because it is a human right in and of itself, but also because it provides one with the ability to seek out other fundamental rights that are owed to them; education is an "empowerment right" (Kalantry, Getgen, \& Koh, 2010, p. 260; UN Committee on Economic, Social and Cultural Rights [CESCR], 1999).

This social human right implies that every individual has the right to access all levels of education. In both the US and Canada, distinctive laws and rulings were made that ensured undocumented immigrants could attend primary public schools without being asked about their legal status. While the right to primary education has been legally established in the US and Canada, as well as in international law, many undocumented immigrants who passed that level of schooling remain in limbo.

In 1954, the US Supreme Court ruled that education is a human right. The case of Brown v. Board of Education of Topeka was appealed to the Supreme Court, regarding the issue of racial segregation in public schools. Although this court case is often remembered for its monumental unanimous decision (9-0) that was in favour of Brown, thereby requiring schools to integrate, it goes beyond the aspect of prohibiting racial discrimination. In its decision, the Supreme Court states, "Where a State has undertaken to provide an opportunity for an education..., such an opportunity is a right which must be made available to all on equal terms" (Brown v. Board of Education, 1954). This ruling clearly notes that no individual is to be denied the opportunity to obtain an education. While this particular case focuses on public primary schools' racially 
discriminatory policies, the final decision does not limit the level of education to which it is applicable, implying that higher education should also be equally accessible.

Meanwhile, Canada has a Supreme Court ruling that—while it may not be as direct as the US Supreme Court verdict—also denounces discrimination and affirms that all individuals have equal rights. The Canadian Charter of Rights and Freedoms (1982) states, "Every individual is equal before and under the law and has the right to the equal protection and equal benefit of the law without discrimination ... based on race, national or ethnic origin, colour, religion, sex, age or mental or physical disability". This assertion implies that everyone is entitled to and cannot be denied basic human rights.

This right was officially extended to non-citizens with the Supreme Court's 1989 ruling in Andrews v. Law Society of British Columbia. While immigrants are not directly mentioned as a group to which discrimination is not permitted, the Andrews v. Law Society of British Columbia (1989) case confirms this notion. To summarize the case, Mark David Andrews was a Canadian permanent resident who wished to be admitted into British Columbia's bar (also known as the Law Society of British Columbia) but was denied. The reason for his denial was because, while he met all of the other requirements, he was not a Canadian citizen. The Supreme Court of Canada ruled in favour of Andrews, validating the argument that one's citizenship status does not impede on one's rights under the Charter of Rights and Freedoms. In their decision, the Supreme Court judges state,

"Section 15(1) of the Charter provides for every individual a guarantee of equality before and under the law, ... without discrimination. Discrimination is a distinction which, whether intentional or not but based on grounds relating to personal characteristics of the individual or group, has an effect which imposes disadvantages not imposed upon others or which withholds or limits access to advantages available to other members of society. Distinctions based on personal characteristics attributed to an individual solely on the basis of association with a group will rarely escape the charge of discrimination, while 
those based on an individual's merits and capacities will rarely be so classed" (Andrews v. Law Society of British Columbia, 1989).

Even though this case addresses whether a Canadian permanent resident is able to access the same opportunities as a citizen, the Supreme Court's decision outlines the type of discrimination that is no longer allowed - discrimination based on one's characteristics. Since Andrews' issue was his permanent residency status in Canada, the ruling implies that one's legal status is a "personal characteristic" that cannot be used to discriminate against their ability to access opportunities that would otherwise be available to them. To that end, one could argue that an undocumented immigrant's legal status cannot deny them access to obtaining an education in Canada.

It is important to note, however, that cases with rulings not in favour of undocumented immigrant also exist. Unlike Andrews v. Law Society of British Columbia, in which undocumented immigrants' rights are validated through a case that involves a person with legal status, there are several cases that expressly deny non-status immigrant rights to equality. The Toussaint v. Canada (Attorney General) case is particularly relevant as it concerns an undocumented immigrant who was denied access to a social human right — health. The appellant arrived in Canada in 1999 as a visitor, overstayed her visa, and continued to live and work in Canada. Upon becoming ill and wishing to seek additional treatment, the appellant attempted to access the Interim Federal Health Program (IFHP) to help cover her emergency medical care. The Federal Court of Appeals ruled against the appellant; it asserted that excluding her from accessing health coverage is permissible because the IFHP only applies to "legal entrants into Canada who are under immigration jurisdiction or for whom immigration authorities feel responsible" (Toussaint v. Canada [Attorney General], 2011). The judges decided that these categories do not apply to the appellant and, thus, her case was denied. The logic behind the court's decision refers to the appellant's "illegal" status when it contends, "Extending these benefits to all foreign nationals in Canada, even those in 
Canada illegally, stretches the program well beyond its intended purpose" (Toussaint v. Canada [Attorney General], 2011). Although court decisions favouring undocumented immigrants' human rights do indeed occur, decisions made directly against non-status immigrant appellants also exist. It is vital that both are discussed to temper the optimism that this paper may evoke if solely proimmigrant court decisions were mentioned.

In addition to domestic legislation, international law has also been established to address the issue surrounding the right to education. The United Nations (UN) created the treaty known as the International Covenant on Economic, Social and Cultural Rights (ICESCR) on December 16, 1966. The US signed but never ratified it, while Canada signed and ratified it on May 19, 1976 (UN General Assembly, n.d.). Signing an international doctrine signifies that the nation agrees to the general terms of the agreement; it expresses the nation's intent to eventually ratify the treaty, but it is not yet binding. Ratification is completed on a domestic level, through a governmental body (e.g. congress or parliament) that passes legislation to implement the treaty's terms; by doing so, the federal government expresses its consent and willingness to be legally bound by the international treaty. As of 2018, 169 states have signed the ICESCR. Those who signed and ratified the ICESCR committed themselves to granting various economic, social, and cultural rightsparticularly labour rights, the right to education, the right to health, and the right to an overall adequate standard of living (UN General Assembly, 1966).

The ICESCR repeatedly states that no individuals should be discriminated against and denied access to the human rights mentioned above-including education. Article 2(2) clearly notes that the parties signing the agreement "guarantee that the rights enunciated in the present Covenant will be exercised without discrimination of any kind as to race, colour, sex, language, religion, political or other opinion, national or social origin, property, birth or other status" (UN 
General Assembly, 1966). While the Covenant does not expressly state that one's immigration status should not be a barrier to access, this distinction arguably falls under the category of "other status" and, therefore, discrimination against this group should not be permitted. Ruth Gavison (2003), a law professor whose research includes human rights and the protection of minors, also makes this argument when she states, "Human rights are rights that 'belong' to every person, and do not depend on the specifics of the individual or the relationship between the right-holder and the right-grantor. Moreover, human rights exist irrespective of the question whether they are granted or recognized by the legal and social system within which we live. ... In other words, human rights are moral, pre-legal rights" (p. 25). Gavison's remarks support the claim that human rights are pre-political and should be granted regardless of one's legal status.

In Article 13(2), the ICESCR distinguishes between the various levels of schooling, and specifies the rights to accessing each one. The primary level must be free and compulsory to all individuals; secondary and higher education, while not compulsory, "shall also be made equally accessible to all, ... in particular by the progressive introduction of free education" (UN General Assembly, 1966). While it may not be free immediately, the Covenant emphasizes that education must be made available and accessible to all.

The Committee on Economics, Social and Cultural Rights (CESCR) claims that the right to education has several essential features, including accessibility (CESCR, 1999). To that end, non-discrimination, economic accessibility, and physical accessibility are the three components of this feature, which a state must address to ensure that it abides by the Covenant (CESCR, 1999). At least two of the three components directly apply to undocumented immigrants. Regarding one's accessibility to education without discrimination, CESCR stresses that "education must be accessible to all, especially the most vulnerable groups, in law and fact, without discrimination on 
any of the prohibited grounds" (CESCR, 1999). Providing access to education without financial barriers is another key issue that faces undocumented immigrants, alongside other socioeconomically marginalized groups. The CESCR asserts, "[E]ducation has to be affordable to all" (CESCR, 1999). Therefore, as the Covenant states, all levels of education should be free (Kalantry et al., 2010, p. 277; UN General Assembly, 1966). However, as the CESCR notes, even if a state does not wish to go to this extreme and provide all levels of education without any fees, it should not create a financial barrier without any funding options for which all potential students can apply.

As previously mentioned, Canada has already ratified the ICESCR, but the US has only signed the Covenant and, therefore, is not obligated to fulfill its provisions. However, the US is still required to meet a certain standard, regardless of whether or not it ratifies a UN agreement. The Vienna Convention on the Law of Treaties, which the US signed in 1970, outlines the regulations on how international treaties are enforced. In the Vienna Convention, Article 18 declares, "A State is obliged to refrain from acts which would defeat the object and purpose of a treaty when ... it has signed the treaty or has exchanged instruments constituting the treaty subject to ratification, acceptance or approval..." (United Nations, 1969, p. 336). Although the US technically does not need to meet the requirements listed in the ICESCR, the Vienna Convention requires all countries that sign an international treaty to-at the very least—refrain from passing laws that directly oppose the objective(s) of the treaty.

In the context of this paper, a signatory can be held accountable if any of its domestic government bodies establish a policy that denies access to post-secondary education. Even though the US has not ratified the Vienna Convention and is not technically bound by it, the decision to sign the agreement implies that the US aims to abide by its terms. In fact, as Krysten Urchick 
(2007) notes, "[T]he articles under the Vienna Convention have been practiced and followed even without its ratification in the U.S. and world-wide. ...Since the Vienna Convention has attained the status of customary international law, U.S. lawmakers and courts will use the Vienna Convention to determine the U.S.'s obligations under these conventions. Therefore, it appears the U.S. bound itself to the terms of the Vienna Convention without official ratification of its terms" (pp. 12-13). Meanwhile, Canada is legally bound to the Covenant, making the country directly responsible for providing all levels of access that are outlined in the treaty. Even though it has successfully ratified the Covenant, unlike the US, the Canadian government—at every level—is still behind several US states with regards to implementing pro-access education policies.

While it is the federal government's responsibility to ratify an international doctrine, any level of government has the ability to implement the treaty. In fact, even if the federal government has not yet ratified an agreement, states and/or municipalities can still move forward with establishing ways to fulfill its requirements. Martha F. Davis (2019) contends that "local governments" are already responsible for addressing matters regarding human rights, such as their constituents' access to food, water, shelter, and education (p. 268). Hence, state, provincial, and municipal governments can "bypass the nation state to interact more directly than ever with international human rights systems, both as norm developers and norm implementers" (Davis, 2019, p. 268). As Davis implies, all levels of government can take on the responsibility to apply the international law and ensure that efforts are being made to protect human rights.

Essentially, the human right to education applies to undocumented immigrants because it asserts that education must be granted to every individual residing within a state, without any prejudice towards one's personal characteristics_-including national political or legal status. It determines that the state cannot decide who can and cannot obtain an education as this would be 
an infringement on a fundamental right. This theoretical framework is applied in this paper because it allows the reader to assess the issue of access to post-secondary education as a basic human right, rather than as a function of national law or policy. As UN Special Rapporteur and human rights lawyer Manfred Nowak (1991) aptly remarks, "[Education] is not only a kind of idealistic goal, ...but a legally binding human right of the majority of the present world population" (p. 425). The human right to education, along with the court rulings and legislation passed on it, justifies the concern behind this ongoing issue and the need for it to be addressed.

\section{Overview of the Topic: Undocumented Immigrants}

\section{$\underline{\text { Statistics }}$}

As of 2016, 10.5 million undocumented immigrants live in the US, making up 3.2\% of the total US population (Krogstad, Passel, \& Cohn, 2019). Within this group, there are approximately 360,000 individuals between 18-24 years old who have graduated high school, along with an additional 715,000 minors who are in grades K-12 (Jefferies, 2008, p. 249). According to a US non-profit organization known as the College Board, 65,000 undocumented immigrants graduate from US high schools annually (Wanielista \& Demay, 2014). Unfortunately, less than $10 \%$ of these graduates continue their education by attending post-secondary institutions (Ibarra, 2013, p. 437). The reason for their decision not to pursue higher education is uncertain and may vary, but a lack of accessibility—procedural and financial—could be a strong deterrent.

Based on figures from 2009, there are between 200,000 and 500,000 individuals living in Canada without legal status - totalling $0.5 \%$ to $1.3 \%$ of the national population (Meloni, Rousseau, Ricard-Guay, \& Hanley, 2017, p. 15). Approximately $25 \%$ of this population are minors. These statistics are not only a decade old, but they are not nearly as accurate as those obtained in the US. 
The information obtained through the US census is cross-referenced with other public records to calculate a more precise number. Meanwhile, Canada's number is a "guesstimate", leaving us with no reliable nor accurate figures regarding this portion of the population. In fact, the actual statistics may be even greater than the estimates made. Professors Lilian Magalhaes, Christine Carrasco, and Denise Gastaldo (2010), from University of Western Ontario and UofT, stress this notion when they state,

“In 2003, Ontario's Construction Secretariat purported that there were 76,000 non-status immigrants in Ontario's construction industry alone, while other sources confirmed that at least 36,000 failed refugee applicants had never been deported, and another 64,000 individuals overstayed their work, student or visitor visas in 2002. If it is assumed that workers are accompanied by family, the numbers in Ontario would rise to the highest figure previously estimated for all of Canada" (p. 2).

Although this research is also dated, it emphasizes a key point: the nation-wide figures available today are inaccurate. It supports the argument that the current population of undocumented immigrants in Canada has not only been overlooked, but has likely increased and exceeded the estimates made over ten years ago.

Nevertheless, if one were to disregard these shortcomings and assume that this data is still relevant today, then the percentage of undocumented minors living in Canada is particularly staggering. Compared to the US figures, which indicate that roughly $1 \%$ of its undocumented population are minors, Canada's 25\% statistic is significantly higher. As these individuals will likely complete primary and secondary school, and may wish to pursue post-secondary schooling, their ability to access higher levels of education must be addressed. 


\section{Discussion on the Term "Illegal"}

As mentioned earlier, there are diverse ways by which an individual can become undocumented, ranging from entering the country illegally through an unofficial border crossing to arriving legally and overstaying beyond a visa's expiration date (Wilson, 2009, p. 7; Simich et al., 2007, p. 369). The phrases "illegal immigrant" and "illegal alien" are commonly used to refer to individuals in these situations, who do not hold a secure status in their country of residence.

The term "illegal" holds substantial weight, evoking a negative connotation when referring to immigration. As the University of San Francisco asserts, "Illegal [is] a racially charged slur used to dehumanize and discriminate against immigrants and people of colour regardless of migratory status" (DACA and Undocumented Students, 2019). Thus, it is important to address this minority accurately, rather than using a term that suggests criminality and perpetuates a negative stigma against the group being discussed.

Nevertheless, "illegal" and "illegal alien" are commonly used in today's society as a political tool. Those opposed to providing undocumented immigrants with access to social human rights—-such as education and health services—often use this terminology. This is done intentionally in order to frame this population as criminals. According to Robert M. Entman (1993), "To frame is to select some aspects of a perceived reality and make them more salient in a communicating text, in such a way as to promote a particular problem definition, causal interpretation, moral evaluation, and/or treatment recommendation for the item described" (p. 52). Labelling undocumented immigrants as criminals results in society "automatically questioning their rights to access the benefits of society" (Jefferies, 2008, p. 250). Therefore, framing undocumented immigrants in this negative light leads one to oppose accepting them and offering them assistance. 
While the terminology and its implications are static, the individuals associated with this term are ever changing. Alessandra Miklavcic (2011) discusses this situation, stating, "[I]llegal immigration has become a tangible social reality in countries such as the United States, the European Union, Canada, and Australia. ...Yet illegality is a status that is not fixed[,] but contingent and unstable: it is produced and imposed within shifting relations of power" (p. 499). Essentially, being "illegal" — more accurately referred to as "undocumented" - is unique in that it is not a stagnant status. Rather, it can fluctuate following an election in which a new governmentwith views directly opposite to those of the previous administration — begins passing legislation that affects one's status in either a positive or negative way. The constant uncertainty and vulnerability that undocumented immigrants face juxtapose the unsympathetic negative connotation that "illegal immigrant" implies. Therefore, this terminology will no longer be mentioned in this paper; this marginalized group will be referred to as "undocumented" going forward.

\section{Impact on Mental Health and Well-being}

Psychologist Emily F. Carasco provides a description of undocumented immigrants, noting that they are "legally marginal, physically deportable, and psychologically vulnerable" (Wilson, 2009, p. 9). This concise yet accurate description aptly states the impact on mental health and well-being that such a precarious situation may impose on a person.

Tanya Aberman and Philip Ackerman (2017) conduct interviews with several individuals who are in these uncertain positions to discuss the unique stresses that they face. From these conversations, they conclude, "Countless [individuals] feel caught in a perpetual state of limbo and express immense frustration over lost time, and having to let go of previous aspirations. This 
significantly impacts their mental health and emotional well-being, as they are constantly analyzing where they should be, and how far behind they feel" (Aberman \& Ackerman, 2017, p. 139). Miklavcic (2011) also asserts this notion, suggesting that undocumented immigrants should be granted access to basic social human rights in an effort to lessen the effect that this troubling situation may have on their mental health.

Several articles address this marginalized group's lack of access to services—-specifically health and education (Aberman \& Ackerman, 2017; Goldring, Berinstein, \& Bernhard, 2009; Gonzalez, 2017; Miklavcic, 2011; Simich et al., 2007). While the literature discusses diverse policies that impede on undocumented immigrants' access to various public services, the authors reach a general consensus. That is, changes to the status quo must be made so that individuals in these precarious situations have better access to basic necessities, as this would help sustain their mental well-being.

\section{Access Granted to Primary and Secondary Schools}

The issue regarding an individual's access to education is a difficult one to resolve as it stems from "a more profound ethical question: which [people] should have—or deserve — the right to [access it]" (Meloni et al., 2017, p. 16). This concept applies to all social services, including education, healthcare, housing, etc. Decisions made on this ethical question through court rulings and/or public policies either prevent or provide certain groups with access to these services. Both the US and Canada addressed the issue of an undocumented immigrant's access to education and made respective legislative decisions regarding one's ability to obtain primary and secondary schooling. Although gaps still remain in terms of the effectiveness of these legislations, it is 
important to discuss the advances made in lower education levels relative to post-secondary education.

\section{$\underline{\text { US Legislation }}$}

In the US, access to primary and secondary education was granted through the judicial system, following the US Supreme Court's decision on Plyler v. Doe (1982). In summary, the case involved a class action against a statute that the Texas Legislation passed in 1975. The statute modified the Texas Education Code to limit state funding to public schools that provided undocumented immigrants with access to schooling. The revised education law declared, "[A]ny public free school district of this state shall admit into the public free schools of the district free of tuition all persons who are either citizens of the United States or legally admitted aliens..." (Texas Education Code, 1975, p. 41). The legislation went on to recommend that public institutions should charge tuition fees to residents who are not "legally admitted" into the US to compensate for the reduced state funding amount that they will receive.

With a slight majority (5-4), the US Supreme Court decided in favour of the class action, declaring that Texas' statute infringes on one's Constitutional rights. In their remarks, they state, "The illegal aliens who are plaintiffs in these cases challenging the statute may claim the benefit of the Equal Protection Clause, which provides that no State shall 'deny to any person within its jurisdiction the equal protection of the laws.' Whatever his status under the immigration laws, an alien is a 'person' in any ordinary sense of that term" (Plyler v. Doe, 1982, p. 202). The argument behind the Plyler v. Doe decision echoes that of the Andrews v. Law Society of British Columbia ruling discussed earlier, as both convey that an (undocumented) immigrant is still a "person" and 
should be granted equal rights regardless of their status. This ruling effectively opened primary and secondary institutions' doors to all US residents.

\section{Canadian Legislation}

North of the US, Canada passed the Immigration and Refugee Protection Act (IRPA; the Act) in 2001, to regulate immigration into the country. This document's focus is not on education, but does briefly mention an immigrant minor's right to access schooling. Section 30(2) of the Act reads, "Every minor child in Canada, other than a child of a temporary resident not authorized to work or study, is authorized to study at the pre-school, primary or secondary level" (Immigration and Refugee Protection Act [IRPA], 2001).

Aside from this instruction given in the IRPA, Canada does not currently have any federal judicial or legislative statute that regulates a board of education's decisions on enrolment and access. Rather, provincial policies determine the provision or restriction of access to education. For example, in the case of Quebec, the province requires any individual seeking to enrol themselves or their child in a public school to show proof that they have legal status in Canadawhether it be as a Canadian citizen, asylum seeker, foreign worker, etc. (Meloni et al., 2017, p. 16). If they are unable to provide this information, then they will not be able to enroll in public school.

In some cases, a school's administration may agree to accept a student with certain conditions. The administration may require the minor's parents/guardians to pay a high tuition fee, or may allow the minor to attend classes without being officially enrolled in the Ministry of Education - resulting in the student not receiving a graduation diploma (Meloni et al., 2017, p. 18). These undocumented minors are considered to be "institutionally invisible", meaning that 
their access to education often involves "discretionary practices" which essentially construct the children as being excluded from school (Meloni et al., 2017, p. 15). Overall, the lack of clear laws on how public school institutions should address undocumented immigrants has put this marginalized group in a very precarious situation regarding access to education.

To that end, the Toronto District School Board realized that it needed to address this issue at the municipal level. Even though Ontario passed the Education Act in 1990, the province left the task of establishing directives based on this legislation to the school districts. In 2007, the Toronto District School Board passed the Students Without Legal Immigration Status Policy, which prohibits schools from inquiring about a potential student's status; it allows minors to attend primary and secondary schools regardless of their immigration status. Commonly referred to as the "Don't Ask, Don't Tell" (DADT) policy, it asserts, "All children who are qualified to be resident pupils of the Board, including those who are without immigration status in Canada, shall be entitled to admission to school. All children shall be welcomed, regardless of immigration status, and information about them or their families shall not be shared with Immigration authorities" (Toronto District School Board, 2007).

While some may consider the DADT legislation to be a ground-breaking step forward in Canada, others critique the various shortcomings regarding its implementation (Villegas, 2018). Flaws may still exist, but it is important to highlight this policy as it directly addresses the matter of providing access to education for undocumented immigrants. Conversely, on the matter of postsecondary education for individuals in these precarious situations, policy regulations are few and far between.

Indeed, these judicial and legislative decisions are limited successes in terms of providing undocumented immigrants with access to formal education. Regarding the US, Edward Drachman 
(2006) remarks, "Although remaining controversial, the Plyler decision cleared the air on providing free $\mathrm{K}-12$ education to undocumented children. But it left open the question whether its findings could be more broadly applied to post-secondary education” (p. 94). Similar sentiment is shared when looking at Canada, as Toronto's DADT policy allows minors to attend primary and secondary schooling without question, but does not address the opportunities — or lack thereofavailable to these students upon graduating.

\section{The Debate over Providing Access to Post-Secondary Education}

While legislation directly addressing undocumented immigrant minors' right to attend public school has been established, the issue regarding their ability to obtain a post-secondary education remains. Kera Wanielista and Daniel Demay (2014) describe the difficult position that this marginalized group is in when they write, "[U]ndocumented students graduate... each year, launching into a world where they face their first major challenge as an adult: surviving in a culture that protects children, no questions asked, but offers plenty of roadblocks once they reach adulthood." This opinion may be sympathetic towards the undocumented immigrant, but it is not the sole viewpoint on the topic. On the contrary, there is a large divide between the two main stances on this issue, with strong assertions made on both sides.

The pro-immigrant camp makes both emotional and economic arguments in favour of providing undocumented students with access to post-secondary education. Often, they draw attention to exemplary members of this group, emphasizing their ongoing struggle to succeed and that the negative connotation attributed to them is merely an inaccurate stereotype. As Julian Jefferies (2008) explains, "This kind of narrative is a common one, presenting undocumented 
students as hard-working, gifted, and overcoming insurmountable odds only to be disqualified from higher education and from their dream by an unjust law" (p. 250).

While this narrative allows one to sympathize for these individuals, economy-based reasoning helps present an even stronger argument. The pro-immigrant faction asserts that not providing access to post-secondary education results in undocumented immigrants obtaining lowskilled jobs, thereby limiting their ability to improve their economic status in society (Jefferies, 2008, p. 249). Instead, they remain stationary in the low-skilled, low-education demographic, which hinders their economic advancement and allows the negative stereotype allotted to this marginalized population to continue.

For those opposed to offering access to education, their reasoning revolves around taxation and its usage. A common argument is that the government collects taxes from citizens who are legally living and working in the country, yet must spend on providing services not only to citizens, but to undocumented immigrants who-unlike citizens-do not contribute. Kris Kobach, Secretary of State of Kansas, conveys this notion when he remarks, "I don't understand why [the government] would take taxpayer dollars that could be going to US citizens and instead subsidizing the education of non-citizens who could also be deported" (Wanielista \& Demay, 2014).

However, there is sufficient evidence that counters the claim that undocumented immigrants utilize services available to them without equitable contribution. The three main taxes that immigrants, alongside citizens, must pay are: sales tax, property tax, and income tax. For obvious reasons, these taxes are difficult, if not impossible, to avoid and consequently provide substantial fiscal earnings (Isbister, 1996, p. 154). Thus, using this argument to justify denying undocumented immigrants access to education can be easily invalidated. 
Echoing Kobach, Tyler Norris - chairman of the University of Texas (UT) chapter of the Young Conservatives of Texas_claims, "Every student at UT who is also an illegal immigrant takes away resources and admission spots from people who are not here illegally" (Mangan, 2010). This remark reiterates the notion that offering accessibility to undocumented students will diminish the funding offered to citizens. Norris not only believes that allowing undocumented immigrants to enroll at UT will impede on "legal" students' opportunities, but also describes these individuals as "illegal". As mentioned earlier, this terminology creates a framework that portrays this marginalized group in a negative light. Regarding the pro-immigrant versus anti-immigrant debate, this negative frame changes the language used in the conversation and helps "sway traditional adherents of a pro-immigration stance" (Jefferies, 2008, p. 250).

This debate will likely persist as both sides have strong views and find it difficult to compromise their beliefs. Still, it is vital to relay factual, unbiased information regarding this issue so that an individual can assess the facts at hand and make a logical decision on his/her stance.

\section{Barriers to Accessing Post-Secondary Education}

For undocumented immigrants, there are various barriers to accessing higher education in the US and Canada, including legal, procedural, and financial impediments. Some states passed legislations that prohibit undocumented students from attending post-secondary institutions. In states and/or provinces that do not have such strict laws in place, barriers still remain. The most prominent obstacles are procedural hindrances and financial burdens. These barriers will be discussed by citing several US states' restrictive policies and Ontario's obstructions in the Canadian context. 


\section{Barriers in the US}

The barriers to accessing higher education vary from state to state, ranging from undocumented students solely facing financial burdens to applicants being denied entirely due to their legal status. While 18 US states currently allow undocumented immigrants to attend public universities (and will be discussed later in this paper), three state legislatures passed laws with provisions that are entirely opposite. Alabama, Georgia, and South Carolina are the three states with the strictest US policies for enrolment, as their institutions' registrars require every individual accepted to disclose their status. If the potential student refuses to provide this information or reveals that they hold no legal status in the US, then their acceptance to the institution is automatically revoked.

Alabama, a notably conservative state, has passed several anti-immigrant legislations in recent years - along with the introduction of over 45 bills in the state legislature since 2008 on the immigrant issue (Alabama Policy, 2018). The state's 2011 House Bill 56 is a relatively prominent one as it outlines the limitations placed against undocumented immigrants on obtaining public services and employment. This bill is strongly influenced by a policy that the Alabama Board of Education passed in 2008, which bans undocumented immigrants from attending public two-year colleges (Alabama Policy, 2018).

The Alabama Legislature asserts that restrictions must be made "[b]ecause the costs incurred by school districts for the public elementary and secondary education of children who are aliens not lawfully present in the United States can adversely affect the availability of public education resources to students who are United States citizens...” (H.B. 56, 2011, p. 4). Named the "Beason-Hammon Alabama Taxpayer and Citizen Protection Act", the bill's title further evokes the common misconception that anti-immigrant groups push onto the public. 
For this reason, according to Section 8 of HB 56, "An alien who is not lawfully present in the United States shall not be permitted to enroll in or attend any public post-secondary education institution in [Alabama]. ...[A] public post-secondary education institution officer may seek federal verification of an alien's immigration status with the federal government..." (H.B. 56, 2011, p. 22). Additionally, undocumented immigrants are not eligible for any form of financial aid (H.B. 56, 2011, p. 22). Section 28 of the bill goes further to deter undocumented immigrants from attending a public education institution. It requires all schools to obtain proof of every student's immigration status under the facade that this information will help determine whether the student must complete an English as a Second Language course (H.B. 56, 2011, p. 56).

All of these factors serve as obvious deterrents to undocumented immigrants who wish to apply to post-secondary institutions in Alabama. Overall, Alabama's legislations are "widely considered the most extensive law[s] in the nation for restricting the lives of undocumented immigrants" (Alabama Policy, 2018). Even though this may be the case, Georgia and South Carolina followed suit and also implemented laws that limit accessibility to this minority group.

Georgia's Board of Regents (GBR), which is in charge of state-run university policies, passed two policies in 2010 that essentially ban undocumented immigrants from attaining postsecondary education in the state. Once again, the GBR justifies these policies using a familiar argument - that providing access to undocumented immigrants would impede on citizens' opportunities and drain state funding (Vasilogambros, 2016). To avoid these unwanted outcomes, the GBR passed measures requiring Georgia's top-ranked public universities to confirm the legal status of all prospective students and prohibiting undocumented immigrants from being granted in-state tuition fees (Vasilogambros, 2016). 
A recent case in Georgia sparked media attention as three undocumented immigrants took the GBR to court over the policy that requires high-ranked state universities to verify the "legal presence" of all new students (Estrada v. Becker, 2019). The plaintiffs claimed that this requirement not only violates their Constitutional rights - specifically the $14^{\text {th }}$ Amendment right to equal protection-but also "creates a new alien classification" (von Spakovsky \& Morrison, 2019). Following a number of appeals, the Eleventh District of the US Court of Appeals dismissed the case, deciding in favour of the GBR. The judges' opinion discusses their decision, referring to the commonly used economic logic when they state, "[T] he Policy is rationally related to the state's legitimate interest in responsibly investing state resources" (Estrada v. Becker, 2019). This reason, in addition to the interpretation of federal immigration policies, led to the court's final decision to allow Georgia universities to base admittance on one's legal status in the US.

South Carolina's legislation mirrors those of Alabama and Georgia, as it explicitly denies undocumented immigrants from accessing state-run post-secondary education. In effect since June 2007, House Bill 3620 prohibits undocumented immigrants from receiving any financial assistance, including state funding, scholarships, and grants (South Carolina Policy, 2018). One year later, the state legislature passed House Bill 4400, which directly restricts access to public institutions altogether. Section 59-101-430(A) declares, “An alien unlawfully present in the United States is not eligible to attend a public institution of higher learning in this State... The trustees of a public institution of higher learning in this State shall develop and institute a process by which lawful presence in the United States is verified" (H.B. 4400, 2008). Similar to Alabama and Georgia, South Carolina's verification requirement inhibits individuals who lack official legal status from enrolling in post-secondary institutions. 
Aside from the strict regulations that these three state governments passed, an undocumented immigrant's accessibility varies from state to state. In states that do not have any policies in place to address this concern, undocumented students experience procedural and financial barriers when attempting to access post-secondary education. As a majority of US states' — particularly states that lack any legislation on this issue-procedural and financial challenges are comparable to those in Ontario, these factors will be discussed in depth through the Canadian context.

\section{Barriers in Ontario, Canada}

While there may not be federal or provincial laws in Canada that directly prohibit undocumented immigrants from attending post-secondary institutions, there certainly are distinct aspects of the post-secondary application and enrolment process that pose an issue. Specifically, Ontario's procedural and financial barriers that may hinder undocumented students from continuing into higher level education will be assessed.

\section{Procedural Barriers}

In the province of Ontario, students use Ontario Universities’ Application Centre (OUAC) and Ontario College Application Service (OCAS) to submit their applications for post-secondary studies. These systems may have been established to provide a uniform, streamlined method to submit one's application to various institutions all at once, but they still have shortcomings when evaluating accessibility. As Aberman and Ackerman (2017) astutely remark, "These centres act as the first gatekeepers, requesting that immigration status be acknowledged immediately" (p. 132). Both OUAC and OCAS require the applicant to disclose their current status in Canada in 
order to complete the application. The centres offer the option to select "Other: No Status", implying that the centres would allow an individual without legal status in Canada to apply, so long as they disclose it. Based on Meghan Wilson's (2009) correspondence with the Manager of Processing-Undergraduate Programs at OUAC, Wilson confirms that the centre does not require the applicant to submit any supporting documents as proof of their legal status (p. 19). Rather, OUAC processes all completed applications regardless of their current status in Canada.

However, while Ontario's online application centres claim to keep this information private and not accessible to authorities, undocumented students may still be hesitant to disclose their status. OUAC's Declaration and Notice of Collection, Use, Disclosure and Treatment of Personal Information states, "We and/or the universities notify universities and colleges across Canada and/or other regulatory authorities (e.g., Canadian Border Services Agency [CBSA]), at our absolute discretion..." (OUAC, 2010). Mentioned in the lengthy privacy agreement that a student must accept prior to having their application officially submitted, this declaration may further discourage an undocumented student from applying through these channels. Indeed, OUAC claims that this would only be necessary if the centre suspects an application to be "false, misleading, or if it contains evidence of academic dishonesty or inappropriate or unethical conduct" (OUAC, 2010). Yet, someone in a precarious situation may not risk applying for fear of their status being disclosed to the CBSA, should the processing centre believe that something in their application is invalid for some reason.

Overall, the OUAC and OCAS applications' sole question that inquires about one's legal status could deter undocumented immigrants from applying, thereby limiting their access to obtaining higher education. To that end, although these centres are relatively lenient towards nonstatus applicants when compared to the three restrictive US states mentioned above, they do not 
ensure that other barriers will not arise between applying and enrolling in a post-secondary program.

\section{$\underline{\text { Financial Barriers }}$}

Should an undocumented immigrant apply through OUAC or OCAS and get accepted to a post-secondary institution, it is customary for the university or college to request the individual's Social Insurance Number (SIN) in order to confirm that the student is eligible for domestic tuition fees. On the contrary, if one does not provide this information, the individual would be considered an international student; they would need to obtain the visa necessary for them to legally study in Canada as well as pay international student tuition fees (Wilson, 2009, p. 21).

It is common practice for eligible students to apply for governmental funding to assist them in paying their post-secondary tuition and various school-related expenses. In Ontario, the Ontario Student Assistance Program (OSAP) assesses students' applications to determine how much financial aid they will be given. On average, graduates of four-year university programs receive $\$ 21,515$ in loans; two-year college graduates receive $\$ 12,393$ (Ontario Training, Colleges and Universities, 2014). These amounts do not include the non-repayable grants often awarded to students as well. To put it in perspective, the University of Toronto gathered data regarding its student body's financial support and found that approximately $46 \%$ of its full-time domestic students obtain financial aid from OSAP annually to help cover their tuition fees (Office of the Vice-Provost, 2018). These statistics emphasize how pivotal governmental aid is in providing potential students with the funding necessary for them to pursue higher education.

Unfortunately for undocumented immigrants, the Canadian Student Financial Assistance Act states that "only persons with citizenship, permanent resident, or Protected Person status 
qualify for government student loans," thereby denying the ability for non-status individuals to access public financial support (Wilson, 2009, p. 24). Although not as commonly used as OSAP to fund academia, another potential lender is the bank. However, individuals are only able to apply for a bank loan if they are Canadian permanent residents or citizens (Wilson, 2009, p. 25). Thus, the only remaining option for this marginalized group is to be admitted as an international student and be charged international student fees.

While the pathway to accessing post-secondary education as an international student may appear feasible, it certainly poses obstacles for the undocumented student wishing to attend. Firstly, the process of getting a valid student visa - a requirement for registration in all postsecondary institutions — is challenging, as one must apply for a study permit from outside Canada. The Government of Canada's official website outlines the specifications, prohibiting almost everyone from attaining a study permit within Canada, aside from a select few circumstances (e.g. the individual applying, the individual's spouse/partner, or their parent already has a valid study or work permit) (Citizenship Canada, 2019a). The list of individuals who may be able to apply for a study permit from inside Canada also includes "a minor child in primary or secondary school" (Citizenship Canada, 2019a). However, there is no detailed information as to how an applicant who falls under this particular category—and is also undocumented—could apply for a postsecondary study permit while residing within Canada's borders. Rather, the Application Guide solely focuses on minors who wish to attend Canadian primary or secondary schools (Citizenship Canada, 2019b). In short, aside from a few exceptions, the Canadian government requires everyone who is not a permanent resident or citizen to apply for a study permit in order to legally attend a Canadian institution. 
There is a mandatory $\$ 150$ fee that one must pay to have their study permit application processed, but this is a trivial expense relative to the international student tuition fees that would follow-should the visa be granted. Based on the 2018-2019 academic year, Canada's international undergraduate tuition average $(\$ 27,159)$ is nearly four times greater than the average domestic tuition $(\$ 6,838)$ (Statistics Canada, 2019). Since this paper is focussing on Ontario, it is important to note this province's tuition fees as well: international undergraduate tuition average is $\$ 34,961$ and domestic undergraduate tuition is $\$ 8,838$ (Statistics Canada, 2019). While the percentage gap between international and domestic tuition fees in Ontario matches that of the Canadian average, the difference in monetary amounts is significantly larger in Ontario.

As statistics clearly show, Canadian international student tuition is considerably higher than domestic student tuition. Not only would an undocumented immigrant need to finance their post-secondary education without governmental assistance, but they would need four times more funds to do so. The significant disparity between students with legal status and non-status students regarding post-secondary financial support in Ontario - and Canada as a whole - is evident. Although some may argue that there is no feasible solution for this concern, various US state government and university policies show that successful efforts can be made to reduce these existing barriers.

\section{Efforts Made by US State Governments}

As of 2019, 18 US states and the District of Columbia have passed policies that permit all students who meet certain requirements to be eligible for in-state tuition (National Immigration Law Center, 2019b). Each respective policy outlines what conditions a student must meet to be granted in-state tuition rates; in these particular states, providing proof of one's legal status is not 
required, thereby allowing undocumented immigrants the opportunity to qualify for in-state tuition. These regulations were established either through the state legislature or the state's higher education governing board. Eleven of these states went a step further, by providing undocumented immigrants with access to state financial aid, should they meet the necessary criteria (National Immigration Law Center, 2019a). The states offering post-secondary in-state tuition will be discussed first, followed by those that also provide access to state financial support.

\section{$\underline{\text { Policies Providing Access to In-State Tuition }}$}

In-state and out-of-state tuition fees in the US correspond with the differences between Canadian domestic and international fees. Essentially, in-state tuition is relatively more affordable and is offered to students who meet certain residency stipulations. Eighteen US states currently offer in-state tuition to undocumented students. Listed alphabetically, these states are: California, Colorado, Connecticut, Florida, Illinois, Kansas, Maryland, Minnesota, Nebraska, New Jersey, New Mexico, New York, Oklahoma, Oregon, Rhode Island, Texas, Utah, and Washington (National Immigration Law Center, 2019a).

Despite the fact that Texas is often affiliated with a conservative political stance, it was the first state to pass a pro-immigrant access policy (Flores, 2010, p. 435). On June 6, 2001, the Texas Legislature passed House Bill 1403, which outlines the requirements needed for someone to be considered a resident of the state and, therefore, be eligible for post-secondary in-state tuition rates. According to H.B. 1403, an undocumented immigrant in Texas qualifies for in-state tuition if he/she:

"(1) graduated from a public or private high school or received the equivalent of a high school diploma in this state;

(2) resided in this state for at least three years as of the date the person graduated from high school or received the equivalent of a high school diploma; 
(3) registers as an entering student in an institution of higher education not earlier than the 2001 fall semester; and

(4) provides to the institution an affidavit stating that the individual will file an application to become a permanent resident at the earliest opportunity the individual is eligible to do so" (H.B. 1403, 2001).

Not only was H.B. 1403 significant in starting a trend across the US-leading over one-third of the 50 states to pass similar policies — but the criteria that the bill deemed necessary was reasonable and not too difficult for an undocumented immigrant to achieve.

California followed suit shortly after Texas, as its' Governor signed Assembly Bill 540 (A.B. 540) on October 12, 2001. A.B. 540 addresses public post-secondary education access for "a person without lawful immigration status"; this bill essentially lists the same requirements as those mentioned in Texas' H.B. 1403 (A.B. 540, 2001). The other 16 states mentioned above, along with the District of Colombia, passed laws that provide access to in-state tuition between 2001-2013. All of the bills tend to mirror H.B. 1403 as they include similar conditions regarding years of in-state secondary school one must have completed and the need to sign an affidavit in which the student agrees to pursue obtaining a legal immigration status in the future (National Immigration Law Center, 2019b).

In contrast, four US states (Arizona, Indiana, Missouri, and Ohio) have taken legal measures to ban undocumented immigrants from receiving in-state tuition rates (Mendoza \& Shaikh, 2019; Villarraga-Orjuela \& Kerr, 2017, p. 621). Arizona allowed the public to vote on this issue in November 2006, and a large majority (71.4\%) voted in favour of a law that denies in-state tuition rates to undocumented immigrants (Kobach, 2007, p. 498). The Arizona Legislature listened to its citizens and went on to pass Proposition 300, which states, "[A] person who is not a United States citizen or legal resident and who does not otherwise possess lawful immigration status in this country may not be classified as an in-state student ... for community college or state 
university tuition purposes" (S.C.R. 1031, 2006). Over the next 10 years, Indiana, Missouri, and Ohio passed similar laws that prevent this marginalized group from qualifying for in-state tuition fees.

Unlike the restrictions that Alabama, Georgia, and South Carolina's legislatures put in place, the financial barriers that certain laws (e.g. Proposition 300) pose may not be as extreme as completely denying one's ability to enrol in post-secondary studies if they do not hold any legal status. Nevertheless, these policies create greater obstacles that an undocumented immigrant must surpass to be able to access higher education. According to Kris W. Kobach (2007), "[P]ublic sentiment in most states leans heavily against the idea of offering in-state tuition rates" (p. 496). Hence, it is vital for the public to be aware of the pro-immigrant state policies being implemented, which provide access to post-secondary education for undocumented immigrants without infringing on US citizens' rights.

\section{$\underline{\text { Policies Providing Access to State Financial Aid }}$}

Following the passing of in-state tuition rate legislations discussed above, 11 US state governments were successful in further decreasing the financial burden facing post-secondary undocumented students. As of 2019, California, Colorado, Illinois, Maryland, Minnesota, New Jersey, New Mexico, Oklahoma, Oregon, Texas, and Washington accept undocumented immigrants' applications for state financial aid (National Immigration Law Center, 2019a). These

states' governing bodies understand that, while offering in-state tuition fees is a step in the right direction, it still leaves undocumented immigrants with less access to higher education than their cohorts. 
New Jersey was added to this list of states in 2013 when it simultaneously enacted in-state tuition and financial support policies, upon passing Senate Bill 2479 (S.B. 2479). Its application process is particularly favourable because, unlike many other state policies, a Social Security Number (SSN) is not mandatory for a New Jersey applicant as long as the individual can provide some "proof of verifiable income" and satisfy reasonable requirements (Financial Aid Resources for New Jersey Dreamers, n.d.). Since it is unlikely that an undocumented immigrant would have a valid SSN, this alternative form of verification allows more individuals in precarious situations to be eligible for funding.

As previously noted, the 18 in-state tuition policies have strikingly similar specifications. To qualify for state financial aid, the regulations remained the same in most states. However, certain states listed additional requirements that undocumented immigrants must meet in order to be eligible for financial support. For instance, New Jersey's S.B. 2479 includes the conditions mentioned above, as well as the following: all male applicants between the ages of 18-25 must register with the Selective Service System (SSS), a US agency that holds information on qualified individuals should the federal government reinstate military conscription (Higher Education Student Assistance Authority, n.d.). Although the draft is no longer a tool commonly used in the US, this additional condition discriminates against male undocumented applicants and may deter them from applying for financial aid. Still, New Jersey's S.B. 2479 does aim to benefit undocumented immigrants by providing them with a better chance to access higher education as long as they meet these stipulations.

Oregon is also one of the more recent states to pass a law granting undocumented immigrants in-state tuition rates, with House Bill 2787 coming into effect on July 1, 2013. Then, the state legislature quickly went on to address education funding as well. In 2015, Senate Bill 81 
was passed, establishing a state grant program to improve post-secondary financial aid and help cover the average cost of Oregon community college tuition (Oregon Higher Education Coordinating Commission, 2018). Referred to as the "Oregon Promise", the bill outlines a statewide tuition-free program. However, unlike the other US states that have similar policies, the Oregon Promise also applies to undocumented immigrants (Smith, 2019). This policy brings Oregon even closer to meeting the standards summarised in the ICESCR — particularly the concept of providing free tuition for higher education so that economic barriers are lifted for all residents.

Each of the 18 US states discussed has approved a pro-accessibility law for various reasons, but there is one common objective that is often expressed. According to Ben Cannon-Executive Director of the Oregon Higher Education Coordinating Commission—Oregon's decision to allow undocumented immigrants to attend public universities with in-state tuition fees and qualify for state financial aid is "about justice, fairness and keeping faith with students for whom we've provided a K-12 education. It's arbitrary and unfair to say that now you're 18, so public support for education disappears" (Smith, 2019). This viewpoint stems from the human rights perspective, which supports the pro-immigrant argument. It asserts that such a policy offers an equal opportunity to every individual under its jurisdiction —including undocumented immigrants. While there is always room for improvement, these particular US states are seeking ways to accommodate this marginalized portion of their population.

\section{Efforts Made by US Universities}

In addition to various state governmental efforts, post-secondary institutions across the US are also providing pathways to education. As of January 2019, three public universities have passed policies that offer in-state tuition rates to undocumented immigrants who wish to enrol; 
these state-run institutions are the University of Michigan, University of Hawaii, and University of Maine (Mendoza \& Shaikh, 2019). Legislation regarding access to higher education for undocumented immigrants has yet to be passed in Michigan, Hawaii, and Maine. Hence, the boards of each university took it upon themselves to establish pro-immigrant policies that help reduce the existing procedural and financial barriers to entry.

Meanwhile, in some states whose legislatures already passed in-state tuition and financial aid access bills, actions are being taken to further reduce financial burdens. California state universities are collaborating with immigrant advocates and charitable organizations to form the California Campus Catalyst Fund; this fund offers additional aid to undocumented students attending state universities. Lastly, Georgia's Freedom University will be discussed, as it is a key example of a pro-immigrant initiative taking place in a largely hostile environment to provide undocumented immigrants with access to private post-secondary education. These various institutions present the efforts made towards providing better accessibility to higher education for this marginalized group.

\section{The University of Michigan}

The University of Michigan (UM) was one of the first institutions to establish a formal policy on this issue, when its Board of Regents voted in favour (6-2) of revising its policy regarding the conditions necessary to obtain in-state tuition rates. Prior to this 2013 decision, the state government attempted twice to pass a law on the issue of receiving in-state tuition. One bill, H.B. 5307, was proposed in 2006 and would prohibit undocumented immigrants from being offered instate tuition; another bill, H.B. 4618, was introduced in 2013 and would do the exact opposite by 
offering in-state tuition (Michigan Policy, 2018). However, neither bill received enough votes in the Michigan Legislature to become an official law.

Thus, the UM Board of Regents took it upon themselves to provide marginalized groupsincluding undocumented immigrants - with better access to higher education by revising residency requirements; the modifications were passed in 2013. According to UM's new Guidelines for Qualifying for In-State Tuition, an incoming student may be eligible for in-state tuition if they: (1) attended and graduated from an accredited Michigan secondary school, and (2) attended a Michigan middle/junior school in the two years prior to secondary school (University of Michigan, n.d., p. 2). The UM policy's main requirements are similar to those listed in the state regulations discussed in the previous section, as both focus on the amount of in-state education that has been completed, rather than on one's legal status in the country.

Additionally, the UM Board of Regents went beyond only providing access to in-state tuition. In the following academic year, 2014-2015, UM began a pilot program that offers financial assistance directly to undocumented students (Michigan Policy, 2018). The program provides need-based financial aid through private funding; $\$ 450,000$ USD was available in its first year (Karoub, 2014). As of 2018, the funding program is still in place, but "existence of the program seems precarious" (Lawrence, 2018). Since Elizabeth Lawrence's article (2018) is the most recent publication regarding the UM program, I cannot confirm whether it continues today. Still, through the university's in-state tuition policy changes and financial aid pilot program, UM allows more students wishing to pursue a higher education to do so, irrespective of their legal status. 


\section{The University of Hawaii and the University of Maine}

Similar to Michigan's state government, the Hawaii Legislature also has not approved any law regarding access to post-secondary education. However, public university boards have enough independence to establish their own guidelines. In 2013, the University of Hawaii (UH) voted in favour of R.P. 6.209, a tuition policy that allows undocumented immigrants to qualify for in-state tuition rates and financial assistance if they meet the following conditions: The prospective student (1) lived in Hawaii for at least 12 months; (2) attended and graduated from a public or private secondary school in any US state; and (3) filed an application to obtain a legal immigration status (University of Hawaii Board of Regents, 2013). UH's in-state tuition policy is notably similar to the one established at UM, as well as the legislations passed across 18 US states.

Additionally, the University of Maine System (UMS) also founded a pro-immigrant policy within a state that does not have any official legislation that addresses undocumented students' access to education. The UMS is a state-wide network consisting of seven public universities, with a total enrolment of approximately 30,000 students (University of Maine System, n.d.). The UMS Board of Trustees passed a policy in 2017, which offers in-state tuition rates to all prospective students, so long as they meet the necessary residency requirements-none of which include providing proof of one's legal status (Bleiberg, 2017). This system of public universities essentially decided to put a policy in place that allows all students who reside in Maine to be eligible for in-state tuition, including those who are undocumented.

\section{California Campus Catalyst Fund}

The California Legislature was among the first to allow undocumented immigrants to qualify for in-state post-secondary tuition (A.B. 540, 2001) as well as state financial aid (A.B. 131, 
2011). Since then, California's public institutions joined forces to provide additional funding sources for these particular students. Currently, 32 universities and colleges are involved in an initiative called the California Campus Catalyst Fund, in which the schools collaborate with philanthropic partners and advocates to raise funds that help support undocumented students' fees (Immigrants Rising, 2018; California Campus Catalyst Fund, 2018). Immigrants Rising, a nonprofit organization in charge of administering the funds, accurately describes the Catalyst Fund, stating, "[It is a] grant-making initiative to expand support for undocumented students and their families across the state's three public higher education systems: California Community Colleges, California State University, and University of California. To date, the Fund has raised nearly $\$ 12$ million dollars [USD]" (Immigrants Rising, 2018). The funding gets distributed to each of the post-secondary institutions involved, who then offer them as grants to eligible undocumented applicants. Whether it is a sizeable project like the California Campus Catalyst Fund or a pilot program such as the one at $\mathrm{UM}$, the efforts being made to provide undocumented immigrants with better access to post-secondary financial aid are worth noting.

\section{Freedom University}

As discussed earlier in this paper, Georgia is one of three US states that passed legislation denying individuals without legal status from enrolling in public post-secondary institutions. Nevertheless, a unique initiative is currently taking place in Georgia, in which the state's first and only "sanctuary-esque" institution has been established to help undocumented immigrants access higher education. In 2011, one year after Policy 4.1.6 and Policy 4.3.4 came into effect, Freedom University (Freedom U) was founded in Georgia. According to the university's Executive Director 
Laura Emiko Soltis, Freedom U aims "to empower students to overcome fear and reclaim their dignity and rights as human beings" (Soltis, 2018).

Freedom U was created by a coalition of both documented and undocumented students, alongside professors and immigrant rights activists (Freedom University, n.d.). The curriculum includes social and life science courses, fine arts, and SAT preparation classes, all of which are taught by volunteer professors (Soltis, 2018). Meanwhile, students also work with faculty to find ways to enrol in private universities that are willing to accept them. Freedom $U$ accomplished this feat in 2015, when its partners were able to get Emory University on board, making it the first private university in Georgia to publicly admit undocumented students (Freedom University, n.d.). Since this policy change, Emory University not only accepts all students' applications without asking for their legal status, but also provides need-based financial aid for those accepted (Emory University, n.d.). Within one year of Emory University's announcement, three more private postsecondary schools in Georgia implemented similar changes to their admission policies (Freedom University, n.d.).

Freedom $U$ also campaigns for universities to establish sanctuary campuses so that undocumented students are better protected. This led Emory University to create the Emory Sanctuary Coalition in 2017. Unfortunately, the Georgia Legislature was not in favour of Freedom U's movement, as it passed the nation's first anti-sanctuary campus bill (H.B. 37) that same year. H.B. 37 forbids private post-secondary institutions from implementing any sanctuary policy; the bill defines "sanctuary policy" as any regulation that "prohibits or restricts ... employees of such private post-secondary institution[s] from communicating or cooperating with federal officials or law enforcement officers with regard to reporting status information..." (H.B. 37, 2017). 
Although this legislation brought Emory University's sanctuary policy to a halt, Freedom U responded by creating the MELT ICE (Mass Emergency Lookout Text for Immigration and Customs Enforcement) initiative. Individuals who register for the MELT ICE program receive text message beacons to alert them when ICE agents and/or other law enforcement officers are conducting unlawful searches on university campuses (Kowalski, 2017).

Freedom U continues to gather allies throughout Georgia to help push forward proimmigrant access efforts within a state that is hostile towards this portion of its population. On its own campus and beyond, Freedom $\mathrm{U}$ is an institution that aims to provide a "safe space where undocumented students could continue their education" (Freedom University, n.d.). Overall, the universities discussed in this section are key examples of the efforts being made independent from any government body. They are intended to highlight the autonomy that public and private postsecondary institutions have in establishing policies that can open doors and present undocumented immigrants with their rightful opportunity to access higher education.

\section{The Canadian Initiative}

Contrary to the US, no Canadian governmental body has passed any official legislation regarding access to higher education for undocumented immigrants. As for Canadian postsecondary institutions, however, certain universities are attempting to reduce the obstacles

currently facing undocumented immigrants who wish to pursue post-secondary studies. Ontario universities' respective boards of governors have substantial autonomy over academic and administrative concerns; therefore, they have the ability to lift barriers to access (Wilson, 2009, p. 18). The efforts being made in two of Canada's largest universities, York University and the University of Toronto, will be addressed in this chapter. 


\section{$\underline{\text { York University Pilot Program }}$}

In January 2017, York University (YorkU) began a pilot project that allowed ten individuals who had a precarious immigration status to enrol for an undergraduate degree (Villegas \& Aberman, 2019, p. 77; Wiens, 2018). Referred to as the Access for Students with Precarious Immigration Status (ASPIS) program, it is the first of its kind to be initiated in a Canadian postsecondary institution (Villegas \& Aberman, 2019, p. 76). The YorkU webpage describes it as “academic bridging ... for students who have precarious immigration status (including no status) and have faced barriers accessing post-secondary studies as a result" (York University Department of Sociology, 2018).

The program provides two options for prospective undocumented students: (1) a directentry into the undergraduate program of their choice, provided they are academically capable and mentally prepared to start straight away, or (2) enrolment in a bridging course that focuses on migration studies (e.g. global migration, migrants' inequality, etc.) to introduce the student to postsecondary level expectations (Villegas \& Aberman, 2019, p. 77). The latter pathway not only aims to provide undocumented immigrants with a smooth transition into a full-time undergraduate program of their choice, but also offers a safe space for this marginalized portion of the student body. Often, undocumented immigrants do not disclose their status to others for fear of what the outcome may be (Working Group on Access, n.d.[a]). YorkU's Bridging program allows for students to connect with others who are in similar challenging situations, reducing the isolation that they may feel (Villegas \& Aberman, 2019, p. 77).

In the program's first year, YorkU President Rhonda Lenton expressed that the university aimed to expand access to education over the next five years. YorkU's pilot project was initially funded by the Toronto municipal government, through a Pan Am Games grant that is awarded to 
initiatives that aim "to improve equity, access and human rights" (Wiens, 2018). The City of Toronto's financial support only lasted three months; it was up to YorkU to acquire the necessary funds to continue the program—should it wish to do so. Currently, the program is in its third academic year and has expanded through support from various donors. As of 2018, 28 students successfully completed the Bridging program, 12 students were already enrolled in full-time undergraduate studies, and 20 additional students had been accepted for the 2018-2019 school year (Working Group on Access, n.d.[a]).

In addition to providing access, Lenton also understands that tuition fees will need to be addressed since domestic fees are far more affordable than international fees (Wiens, 2018). Prior to the ASPIS program, undocumented immigrants wishing to pursue higher education at YorkU had to enrol as international students and be charged international fees. Now, individuals enrolled in this particular program are offered domestic tuition rates.

Unfortunately, due to various procedural barriers discussed earlier in this paper, undocumented students are unlikely to obtain financial aid from OSAP to help cover their fees. In an attempt to lessen the gap between expenses and available funding, YorkU's Centre for Refugee Studies (CRS) established the Refugee Student Bursary, which specifically supports students who are refugees or undocumented (York University, n.d.). To be fair, this bursary is the only grant that an undocumented perspective YorkU student is eligible for, and does not offer as much support as could be provided through government-funded aid. However, regarding the CRS Refugee Student Bursary and the YorkU ASPIS program overall, one must admit that —at the very leastthese are tangible efforts made towards reducing the barriers currently in place against undocumented immigrants who wish to access Canadian post-secondary education. 


\section{University of Toronto Proposal}

Meric Gertler, President of the University of Toronto (UofT), claims that the UofT has "the most generous and comprehensive access guarantee in the country" (Working Group on Access, n.d.[b]). While this assertion can be debated, the university has assembled a group to look into providing undocumented immigrants with better access to post-secondary education. Entitled "The Working Group on Access to Higher Education for Students with Precarious Immigration Status" (referred to as the "Working Group" going forward), it is a collaborative effort that involves UofT faculty, staff, and students. The group's primary goal is to create policies that lessen the existing barriers to higher education.

In 2018, the Working Group presented a proposal for a pilot program to be established at the UofT. This program is largely based on the similar ASPIS Bridging program already in place at YorkU. Since the UofT already has the Transitional Year Program and the Academic Bridging Program in place, the proposal argues, "[By] building off their learnings and toolkits, the UofT can effectively launch a program for students with precarious immigration status and ensure the students' success" (Working Group on Access, n.d.[a]). In addition to the pro-access bridging program, the Working Group also addresses the tuition fee issue. Referencing the YorkU policy, the proposal recommends for undocumented students accepted into the UofT program not to be asked for proof of status or a study permit, but to be charged domestic rates rather than international rates (Working Group on Access, n.d.[a]).

The UofT Working Group also wants to ensure that undocumented students can attend classes safely, without fear of being apprehended by immigration officers. They suggest that the UofT implements an 'Access Without Fear' policy, which would allow students to access services (e.g. obtaining a UofT Student Card) without first being required to prove their legal status 
(Working Group on Access, n.d.[a]). Moreover, they advise the UofT to deny access to the campus for CBSA officers, unless the university is notified ahead of time or if it is an "extreme circumstance" (Working Group on Access, n.d.[a]; Working Group on Access, n.d.[b]). These measures would help provide a more secure environment for students who may otherwise hesitate to attend class due to a sense of insecurity.

The Working Group proposal cites various UofT policy documents, which state that one of the university's goals is to establish an "equitable and inclusive community" (Working Group on Access, n.d.[a]). The proposal argues that the university is falling short of achieving this objective as it denies equal access to undocumented students who wish to pursue higher education (Working Group on Access, n.d.[a]). In order to remove these barriers, the Working Group (n.d.[a]) insists, "The UofT should create a program that will allow academically-qualified residents with precarious immigration status to apply and attend university safely and affordably." While this proposal for a pilot program is still in its early stages, it is important to highlight the steps that the UofT is taking towards improving access to post-secondary education. As the UofT proposal often refers to the existing YorkU program, this demonstrates how a university's ambitious goal can be accomplished and then lead to other institutions using these successes as a framework to establish similar policies.

\section{Conclusion}

The undocumented immigrant topic has been a hot-button issue in the US for decades, and continues to be a polarizing issue today. A reason for this may be because of the lengthy southern US border with Mexico, which anti-immigrant factions often refer to when arguing against providing access to so-called "illegal aliens". Meanwhile, Canadian media and politicians do not 
focus on this portion of the population as frequently. Rather, it only comes to the forefront when Canada faces a crisis, such as sudden unauthorized entry or asylum claims on a large scale (Goldring, Berinstein, \& Bernhard, 2009, pp. 245-246). Although this disregard may appear as beneficial for undocumented immigrants who wish to remain under the radar, it also creates barriers against accessing social human rights - particularly education. Indeed, US and Canadian statutes that provide primary and secondary schooling to all minors regardless of their legal status have been established. However, upon graduating from secondary school, an undocumented student has limited options to continue their education. Instead of being offered opportunities, they are likely to face various roadblocks.

Barriers define the availability of a service on the basis of one's immigration status. Undocumented immigrants encounter legal, procedural, and/or financial challenges when applying to post-secondary institutions in the US or Canada. These barriers range from financial burdens without public financial assistance to a complete ban against non-status student enrolment (Villegas, 2018, p. 1111). Nevertheless, 18 US state governments, several US universities, and two Ontario universities either already implemented or plan to implement policies that increase access to education. The pro-immigrant policies include refraining from asking potential students about their legal status, offering in-state/domestic tuition rates, and/or providing financial aid for those who qualify. Whether they were passed through a state legislature or a university's board of regents, these policy changes aim to provide better accessibility to higher education for immigrant students in precarious situations.

University of Texas Professor Hugo Ibarra (2013) muses about the benefits that accessibility would bring not only to the undocumented immigrant but to society overall. He urges public figures and institutions to address this issue when he states, 
"Undocumented residents will find work, one way or another, with or without papers; they will either incorporate into the formal economy, ... or they will continue to live in the shadows away from demographers, immigration authorities, school records, universities, credit rating agencies, banks, medical organizations, tax collection and law enforcement agencies. Unless efforts become more evident and intentional on the part of school districts, universities and society, it is possible that the majority of these students will continue to 'disappear' after graduation” (pp. 450-451).

Although significant achievements have been discussed thus far, the US and Canada still have room to further address this issue. Canada falls far behind 18 US states that passed and implemented pro-access legislations. However, since these US policies are already in place, Canadian government bodies can assess their effectiveness and use them as templates to form their own post-secondary education access policies.

Since there are no provincial or federal laws that prohibit post-secondary schools from accepting undocumented students, these institutions have enough autonomy to lift certain barriers that are currently in place. Canadian universities can also learn from the actions taken in the US and work towards establishing similar policies. As Paloma E. Villegas and Tanya Aberman (2019) advise, "Universities and colleges across Canada can also adopt inclusionary practices to counter their presence as racialized and immigration status centred sites, to reduce the barriers that prevent certain students from following their dreams" (p. 79). YorkU's ASPIS Bridging program and the UofT's program proposal are clear examples of Canadian initiatives that are influenced by various US efforts. To be fair, it is always best to assess an initiative through a critical lens to see where further advancements are possible. In YorkU's case, the ASPIS program solely applies to students looking to access undergraduate programs. If a student who enrolled in YorkU through the ASPIS program wishes to pursue post-graduate studies - a master's degree or $\mathrm{PhD}$ - they would be restricted yet again. Perhaps the next step at YorkU would be to expand this program to all levels of higher education. 
In the Canadian context, undocumented immigrants tend to get overlooked, but they are undeniably present. Hence, this marginalized group must be acknowledged and granted the social human rights to which they are entitled. Both governmental and non-governmental institutions should abide by domestic and international laws; they should increase efforts to provide non-status residents with access to all levels of schooling-including post-secondary education.

The social human right to education has been acknowledged in several international treaties by both the US and Canada, yet (in)direct barriers still remain. This MRP's findings highlight various domestic policies and programs that were implemented to provide more individuals with access to this human right. However, these are not federal policies; gaps and barriers to access still remain depending on where the undocumented immigrant lives. Neither country's federal government has passed a law that enforces the requirements outlined in the ICESCR, thereby allowing lower level institutions to decide where to abide by the UN doctrine or reject it. The latter can be seen in states such as Alabama, Georgia, and South Carolina; since the US has not ratified the ICESCR, statutes that are directly against undocumented immigrants' access to education have been established. In order to prevent this from occurring, the federal government must recognize that, as a signatory of the ICESCR, it is symbolically committed to implementing the treaty's components. To that end, it should go beyond just being in favour of the treaty symbolically, but, rather, guarantee that its terms are met. If the federal government fails to do so, then state, provincial, and/or municipal institutions must take it upon themselves to ensure that this international agreement is put into effect within their respective jurisdictions. Whether it is enforced through a top-down or bottom-up approach, the social human right to (post-secondary) education has to be accessible to everyone, regardless of their legal status. 


\section{Bibliography}

A.B. 131, 2011 Legis. Assemb., Reg. Sess. (Cal. 2011).

A.B. 540, 2001 Legis. Assemb., Reg. Sess. (Cal. 2001).

Aberman, T., \& Ackerman, P. (2017). Isn't the right to an education a human right? In Sara Carpenter \& Shahrzad Mojab (Eds.), Youth as/in crisis: Young people, Public Policy, and the Politics of Learning (pp. 127-144). Sense.

Alabama Policy. (2018, January 12). Retrieved from https://uleadnet.org/map/alabama-policy

Andrews v. Law Society of British Columbia. (1989). 1 S.C.R. 143. Retrieved from https://scccsc.lexum.com/scc-csc/scc-csc/en/item/407/index.do

Associated Press. (2008, September 29). Alabama board bars undocumented students from community colleges. Retrieved from https://diverseeducation.com/article/11743/

Bleiberg, J. (2017, September 5). Undocumented Mainers eligible for in-state tuition at UMaine schools. Retrieved from https://bangordailynews.com/2017/07/15/education/umaineschools-offer-in-state-tuition-to-undocumented-immigrants-in-federal-program/

Brennan, W. J. \& Supreme Court Of The United States. (1981) U.S. Reports: Plyler v. Doe, 457 U.S. 202. [Periodical] Retrieved from the Library of Congress, https://www.loc.gov/item/usrep457202/.

Brown v. Board of Education, 347 U.S. 483 (1954)

California Campus Catalyst Fund. (2018). What we fund. Retrieved from https://californiacatalystfund.org/about-the-catalyst-fund/what-we-fund/

Canadian Charter of Rights and Freedoms, s 15, Part I of the Constitution Act, 1982, being Schedule B to the Canada Act 1982 (UK), 1982, c11.

Citizenship Canada. (2019a, June 4). Study permit: How to apply. Retrieved on June 30, 2019 from https://www.canada.ca/en/immigration-refugees-citizenship/services/studycanada/study-permit/apply.html

Citizenship Canada. (2019b, June 12). Guide 5552 - Applying to change conditions or extend your stay in Canada - student - online application. Retrieved on June 30, 2019 from https://www.canada.ca/en/immigration-refugees-citizenship/services/application/ application-forms-guides/guide-5552-applying-change-conditions-extend-your-staycanada-student.html

Crépeau, F., Nakache, D., \& Atak, I. (2007). International migration: Security concerns and human rights standards. Transcultural Psychiatry, 44(3), 311-337. 
DACA and Undocumented Students. (2019, February 18). Retrieved from https://www.usfca.edu/education/admission-and-aid/undocumented-students

Davis, M. F. (2019). Scoping the new urban human rights agenda. The Journal of Legal Pluralism and Unofficial Law, 51(2), 260-270.

Dougherty, K. J., Nienhusser, H. K. \& Vega, B. E. (2010). Undocumented immigrants and state higher education policy: The politics of in-state tuition eligibility in Texas and Arizona. The Review of Higher Education 34(1), 123-173.

Drachman, E. (2006). Access to higher education for undocumented students. Peace Review, 18(1), 91-100.

Emory University. (n.d.). Undocumented students. Retrieved from https://apply.emory.edu/ apply/other/undocumented.html

Entman, R. M. (1993). Framing: Toward clarification of a fractured paradigm. Journal of Communication, 43(4), 51-58.

Estrada v. Becker, 917 F.3d 1298 (11 ${ }^{\text {th }}$ Cir. 2019)

Financial Aid Resources for New Jersey Dreamers. (n.d.). Retrieved from https://www.hesaa.org/Pages/NJAlternativeApplication.aspx

Flores, S. M. (2010). The first state dream act: In-state resident tuition and immigration in Texas. Educational Evaluation and Policy Analysis, 32(4), 435-455.

Freedom University. (n.d.). Timeline. Retrieved from https://freedom-university.org/timeline

Gavison, R. (2003). On the relationships between civil and political rights, and social and economic rights. In J. Coicaud, M.W. Doyle, \& A. Gardner (Eds.), The globalization of human rights (pp. 23-55). New York, NY: United Nations University Press.

Goldring, L., Berinstein, C., \& Bernhard, J. K. (2009). Institutionalizing precarious migratory status in Canada. Citizenship Studies, 13(3), 239-265.

Gonzales, R. G. (2011). Learning to be illegal: Undocumented youth and shifting legal contexts in the transition to adulthood. American Sociological Review, 76(4), 602-619.

H.B. 37, 2017 Leg., Reg. Sess. (Ga. 2017).

H.B. 56, 2011 Leg., Reg. Sess. (Ala. 2011).

H.B. 1403, 2001 Leg., $77^{\text {th }}$ Reg. Sess. (Tex. 2001). 
H.B. 4400,2008 Gen. Assemb., $117^{\text {th }}$ Sess. (S.C. 2008).

Higher Education Student Assistance Authority (n.d.). Frequently asked questions for New Jersey Dreamers [PDF file]. Retrieved from https://www.hesaa.org/Documents/NJAltAPPQnA.pdf

Ibarra, H. (2013). Facing the giant: Higher education access and financial assistance for undocumented students in Texas. International Journal of Leadership in Education, 16(4), 435-453.

Immigration and Refugee Protection Act (IRPA) [Canada], SC 2001, c. 27, 1 November 2001. Retrieved from https://laws-lois.justice.gc.ca/eng/acts/i-2.5/FullText.html

Immigrants Rising. (2018). CA Campus Catalyst Fund. Retrieved from https://immigrantsrising.org/educational-partnerships/ca-campus-catalyst-fund/

Isbister, J. (1996). The immigration debate: remaking America. West Hartford, CT: Kumarian Press.

Jefferies, J. (2008). Do undocumented students "play by the rules"? Journal of Adolescent \& Adult Literacy, 52(3), 249-251.

Kalantry, S., Getgen, J., \& Koh, S. (2010). Enhancing enforcement of economic, social, and cultural rights using indicators: A focus on the right to education in the ICESCR. Human Rights Quarterly, 32(2), 253-310.

Karoub, A. (2014, September 7). How the new in-state tuition policy impacts international students. Retrieved from https://www.michigandaily.com/article/coalition-tuitionequality-0

Kobach, K. W. (2007). Immigration nullification: In-state tuition and lawmakers who disregard the law. New York University Journal of Legislation and Public Policy 10(3), 473-524.

Kowalski, D. M. (2017, May 28). Freedom University's MELT ICE project. Retrieved from https://www.lexisnexis.com/legalnewsroom/immigration/b/insidenews/posts/freedomuniversity-39-s-melt-ice-project

Krogstad, J. M., Passel, J. S., \& Cohn, D. (2019, June 12). 5 facts about illegal immigration in the U.S. Retrieved July 1, 2019 from https://www.pewresearch.org/facttank/2018/11/28/5-facts-about-illegal-immigration-in-the-u-s/

Lawrence, E. (2018, March 6). Undocumented students work with university to provide more resources. Retrieved from https://www.michigandaily.com/section/community-affairs/ undocumented-students-work-university-provide-more-resources-0

Maine Policy. (2018, January 9). Retrieved from https://uleadnet.org/map/maine-policy 
Magalhaes, L., Carrasco, C., \& Gastaldo, D. (2010). Undocumented migrants in Canada: a scope literature review on health, access to services, and working conditions. Journal of Immigrant and Minority Health, 12(1), 132-151.

Mangan, K. (2010). Illegal voices: Undocumented students. The Chronicle of Higher Education, Retrieved from http://ezproxy.lib.ryerson.ca/login?url=https://searchproquest-com.ezproxy.lib.ryerson.ca/docview/756337869?accountid=13631

Meloni, F., Rousseau, C., Ricard-Guay, A., \& Hanley, J. (2017). Invisible students: Institutional invisibility and access to education for undocumented children. International Journal of Migration, Health and Social Care, 13(1), 15-25.

Mendoza, G. S., \& Shaikh, N. (2019, January 16). Tuition benefits for immigrants. Retrieved from http://www.ncsl.org/research/immigration/tuition-benefits-for-immigrants.aspx

Merriam, S. B., Johnson-Bailey, J., Lee, M., Kee, Y., Ntseane, G., \& Muhamad, M. (2001). Power and positionality: Negotiating insider/outsider status within and across cultures. International Journal of Lifelong Education, 20(5), 405-416.

Michigan Policy. (2018, January 16). Retrieved from https://uleadnet.org/map/michigan-policy

Miklavcic, A. (2011). Canada's non-status immigrants: Negotiating access to health care and citizenship. Medical Anthropology, 30(5), 496-517.

National Immigration Law Center. (2019a, July). Access to Postsecondary Education. Retrieved from https://www.nilc.org/issues/education/eduaccesstoolkit2a/\#tables

National Immigration Law Center. (2019b, July). Laws \& policies improving access to higher education for immigrants [PDF file]. Retrieved from https://www.nilc.org/wp-content/ uploads/2017/10/table-access-to-ed-toolkit.pdf

Nowak, M. (1991). The right to education - Its meaning, significance and limitations. Netherlands Quarterly of Human Rights, 9(4), 418-425.

Office of the Vice-Provost, Students. (2018, March 12). Annual Report on Student Financial Support, 2016-17. Retrieved from https:/www.provost.utoronto.ca/wpcontent/uploads/sites/155/2018/05/Annual-Report-Student-Financial-Support-201617.pdf

Ontario Training, Colleges and Universities. (2014, April 25). Average OSAP Debt. Retrieved from https://www.ontario.ca/data/average-osap-debt

Ontario Universities' Application Centre (OUAC). (2010, June 18). OUAC 101 Declaration and Notice. Retrieved from https://www.ouac.on.ca/privacy/101-declaration/ 
Oregon Higher Education Coordinating Commission. (2018, December). Senate Bill 81 (2015): The Oregon Promise - Report from year 3 [PDF file]. Retrieved from https://www.oregon.gov/highered/research/Documents/Reports/SB-81-Oregon-Promise2018.pdf

S.B. 81, $78^{\text {th }}$ Legis. Assemb., Reg. Sess. (Or. 2015).

S.B. 2479, 2013 Leg., Reg. Sess. (N.J. 2013).

S.C.R. 1031, $47^{\text {th }}$ Leg., $2^{\text {nd }}$ Reg. Sess. (Ariz. 2006).

Simich, L., Wu, F., \& Nerad, S. (2007). Status and health security: An exploratory study of irregular immigrants in Toronto. Canadian Journal of Public Health, 98(5), 369-73.

Smith, A. A. (2019, March 12). More states are encouraging undocumented students to pursue tuition-free programs. Retrieved from https://www.insidehighered.com/news/2019/03/12/ more-states-are-encouraging-undocumented-students-pursue-tuition-free-programs

Soltis, L. E. (2018). Freedom University: "Where you walk in undocumented and leave unafraid". Retrieved from https://www.aacu.org/diversitydemocracy/2018/summer/soltis

South Carolina Policy. (2018, January 11). Retrieved from https://uleadnet.org/map/southcarolina-policy

Statistics Canada. (2019, July 22). Canadian and international tuition fees by level of study. Retrieved from https://www150.statcan.gc.ca/t1/tbl1/en/tv.action?pid=3710004501

Texas Education Code, $\S 21.031-21.0311$ (1975).

Toronto District School Board. (2007, May 16). Summary of decisions regular meeting [PDF file]. Retrieved from https://www.tdsb.on.ca/Leadership/Boardroom/AgendaMinutes/Type/M/Year/2007?Filename=70516.pdf

Toussaint v. Canada (Attorney General), 2011 FCA 213, CanLII.

UN Commission on Human Rights, The right to education: Report submitted by Katarina Tomasevski, Special Rapporteur: Addendum Mission to Colombia, 15 January 2004, E/CN.4/2004/45. Retrieved from https://documents-ddsny.un.org/doc/UNDOC/GEN/G04/103/32/PDF/G0410332.pdf?OpenElement

UN Committee on Economic, Social and Cultural Rights (CESCR), General Comment No. 13: The Right to Education (Art. 13 of the Covenant), 8 December 1999, E/C.12/1999/10. Retrieved from https://www.refworld.org/docid/4538838c22.html 
UN General Assembly, International Covenant on Economic, Social and Cultural Rights, 16 December 1966, United Nations, Treaty Series, vol. 993, p. 3. Retrieved from https://treaties.un.org/doc/Treaties/1976/01/19760103\%2009-57\%20PM/Ch_IV_03.pdf

UN General Assembly. (n.d.). Status of Signatories Chapter IV Human Rights. Retrieved from https://treaties.un.org/Pages/ViewDetails.aspx?src=IND\&mtdsg_no=IV-3\&chapter $=4 \&$ clang $=\_$en

United Nations, Vienna Convention on the Law of Treaties, 23 May 1969, United Nations, Treaty Series, vol. 1155, p. 331. Retrieved from https://treaties.un.org/doc/Publication/ UNTS/Volume\%201155/volume-1155-I-18232-English.pdf

University of Hawaii Board of Regents. (2013, February 21). Board of Regents Policy 6.209. Retrieved from https://www.hawaii.edu/policy/?action=viewPolicy\&policySection=Rp\& policyChapter $=6 \&$ policyNumber $=209$

University of Maine Farmington. (n.d.). Application for Undergraduate Admission [PDF file]. Retrieved from https://www.umf.maine.edu/admissions-aid/wp-content/uploads/ sites/4/2018/08/UMF-Application-2017-2018.pdf

University of Maine System. (2009, November 16). Policy Manual - Section 703 Tuition and Fees. Retrieved from https://www.maine.edu/about-the-system/board-of-trustees/policymanual/section703/

University of Maine System. (n.d.). About the System. Retrieved from http://www.maine.edu/ about-the-system/

University of Michigan. (n.d.). University of Michigan guidelines for qualifying for in-state tuition [PDF file]. Retrieved from http://catalog.umd.umich.edu/graduate/registrationrecords/guidelines-qualifying-in-state-tuition/guidelines-qualifying-in-state-tuition.pdf

University System of Georgia. (2010a). Section 4.1: General Policy on Student Affairs. Retrieved from https://www.usg.edu/policymanual/section4/C327/

University System of Georgia. (2010b). Section 4.3: Student Residency. Retrieved from https://www.usg.edu/policymanual/section4/C329/

Urchick, K. (2007). U.S. education law: Is the right to education in the U.S. in compliance with international human rights standards? [PDF file]. Retrieved from http://www.law.msu.edu/king/2007/Urchick.pdf

Vasilogambros, M. (2016, March 16). The folly of under-educating the undocumented. The Atlantic. Retrieved from https://www.theatlantic.com/politics/archive/2016/03/the-follyof-under-educating-the-undocumented/473877/ 
Villarraga-Orjuela, A., \& Kerr, B. (2017). Educational effects of banning access to in-state resident tuition for unauthorized immigrant students. Educational Evaluation and Policy Analysis, 39(4), 620-643.

Villegas, F. J. (2018). 'Don't ask, don't tell': Examining the illegalization of undocumented students in Toronto, Canada. British Journal of Sociology of Education, 39(8), 11111125.

Villegas, P. E., \& Aberman, T. (2019). A double punishment: The context of postsecondary access for racialized precarious status migrant students in Toronto, Canada. Refuge: Canada's Journal on Refugees, 35(1), 72-82.

von Spakovsky, H. A., \& Morrison, C. (2019, April 1). No right to college for illegal immigrants. The Heritage Foundation. Retrieved from https://www.heritage.org/immigration/commentary/no-right-college-illegal-immigrants

Walsh, J. P. (2011). Quantifying citizens: Neoliberal restructuring and immigrant selection in Canada and Australia. Citizenship Studies, 15(6-7), 861-879.

Wanielista, K., \& Demay, D. (2014, August 31). A path to nowhere. TCA Regional News. Retrieved from http://ezproxy.lib.ryerson.ca/login?url=https://search-proquestcom.ezproxy.lib.ryerson.ca/docview/1558519525?accountid=13631

Wiens, M. (2018, January 15). York first Canadian university to give 'Dreamers' a chance at a degree. CBS News. Retrieved from https://www.cbc.ca/news/canada/toronto/canadiandreamers-york-university-1.4488252

Wilson. M. (2009). Access to postsecondary education for undocumented immigrants [PDF file]. Retrieved from https://we.riseup.net/assets/17110/WilsonM-

LawReformPAPER1_pdf.pdf

Working Group on Access to Higher Education for Students with Precarious Immigration Status, University of Toronto. (n.d.[a]). Position Paper-Access for students with precarious immigration status: Proposal for a pilot program at the University of Toronto (UofT). Unpublished manuscript.

Working Group on Access to Higher Education for Students with Precarious Immigration Status, University of Toronto. (n.d.[b]). Removing barriers: A fact sheet on access to education in Canada for students with precarious immigration status. Unpublished manuscript.

York University. (n.d.). Centre for Refugee Studies. Retrieved from https://crs.info.yorku.ca/

York University Department of Sociology. (2018). Options for Students with Precarious Immigration Status. Retrieved from http://soci.laps.yorku.ca/dreamers/ 